\title{
Evaluating Urban Status of Informal Settlements in Indonesia: A Comparative Analysis of Three Case Studies in North Jakarta
}

\author{
Waleed S Alzamil ${ }^{1}$ \\ ${ }^{1}$ Department of Urban Planning, College of Architecture and Planning, King Saud University, Saudi Arabia \\ Correspondence: Waleed S Alzamil, Department of Urban Planning, College of Architecture and Planning, King \\ Saud University, Saudi Arabia. E-mail: waalzamil@ksu.edu.sa
}

Received: June 6, 2018

Accepted: July 5, $2018 \quad$ Online Published: July 29, 2018

doi:10.5539/jsd.v11n4p148

URL: https://doi.org/10.5539/jsd.v11n4p148

\begin{abstract}
Informal settlements have become one of the most important issues facing urban areas in Indonesia. The emergence of informal settlements, called 'kampungs', in Jakarta has accompanied the rapid urbanization, and it has become more serious in recent decades. This paper evaluates the urban status of informal settlements in Jakarta. The methods used include a comparative analysis of three case studies in North Jakarta: A. Kampung Bandan; B. Kampung Luar Batang; and C. Kampung Muara Baru. This paper founds that upgrading these settlements must be in accordance with a comprehensive plan that includes priority improvements. The paper proposes integrating the local community into informal area improvement processes because they are aware of their actual needs.
\end{abstract}

Keywords: evaluating, informal, settlements, physical, urban, Kampung, Jakarta, Indonesia

\section{Introduction}

In Asia, poverty remains one of the main reasons for the emergence of informal settlements, with a population of 60 percent of the world's 1.25 billion poor (Bank, 2014). According to World Bank statistics, 758 million people in Asia are still below the $\$ 1.25$ poverty line (Bank, 2014). Moreover, more than 523.2 million people in Asia out of a total of 862.6 million people living in informal settlements worldwide, which make up 60 percent of the world's informal population (UN-Habitat, 2012b). In Asia, 30\% of the urban population resides in these settlements (UN-Habitat, 2013). Millions of poor households are unable to afford housing due to housing supply and finance is limited (UN-Habitat, 2011). Poor households spend a large part of their income on housing at the expense of spending on other basic needs, such as food, education and health. Therefore, they reside in informal housing and slums which provide them with affordable options (UN-Habitat, 2011).

Jakarta has great importance as economic center of Indonesia, the largest Islamic country that has more than 300 ethnic and linguistic groups (Worldpopulationreview, 2017). It is a trade, tourism and cultural center, with a population of 10,075,310 that jumps to $11,200,000$ in the daytime due to individuals who commute into the city for work (Wright, 2016). The actual figure might be far beyond this official number due to illegal migrants who are not registered in official population data. Recent statistics indicate that Jakarta ranks 25 th in the ranking of the world cities populations (Worldpopulationreview, 2017). Jakarta is one of the largest cities that still suffering from the proliferation of informal settlements, which are often called 'kampungs'. The term kampung in Javanese tradition refers to the village or urban community. These areas could be formal or informal settlements that are characterized by pockets of poverty, lack of services, and infrastructure (Baker, 2012). In Jakarta, informal settlements have emerged as a result of the lack housing policies to accommodate residents' economic and social needs. Low income families and poor immigrant communities are unable to afford the cost of housing due to the cost of construction materials, land management systems, and housing policies. Therefore, they live in self-built settlements on government land without legal ownership and form their own social and cultural networks in accordance with their economic conditions (Miller, Bobbette, \& Turpin, 2012). These settlements are built along the waterways, railways, natural rivers and reservoirs that are owned by the central government (WorldBank, 2011).

kampungs do not have land tenure security where the government allows residents to settle as a temporary solution to housing the poor without guarantees of non-evacuation (Miller et al., 2012, p. 236). Fig. 1 shows the percentages of land tenure in Jakarta where more than $50 \%$ of the land parcels are unregistered with the 
government. Most of kampungs lands are illegally built and later converted into informal settlements (Leaf, 1993). According to UN-Habitat (2003), there are 360 kampungs classified as informal settlements in Jakarta. These areas cover approximately $20 \%-30 \%$ of the total area of Jakarta (Prasetyanti, 2015, p. 113). The estimated number of people living in these settlements is more than half of the total population of Jakarta (Subroto, 2006, $p$. 1). Moreover, the physical conditions of these kampungs do not meet the standards of modern residential environments. Informal settlements in Jakarta have become worthy of government attention over the past several decades. The government deals with informal settlements through evacuation, demolition, or resettlement policies in adjacent urban blocks (UN-Habitat, 2008). These solutions do not reflect a deep understanding of urban configuration of informal settlements. Therefore, the government faces numerous protests from NGOs and civil society on current policies to address informal settlements (Baker, 2012).

This paper aims to evaluates the current urban status of the informal settlements in Jakarta to understand the existing patterns of the environment build for addressing them. The methods used include a comparative analysis of three case studies in North Jakarta: A. Kampung Bandan; B. Kampung Luar Batang; and C. Kampung Muara Baru. The literature discusses urbanization issues and government efforts to improve informal settlements in Jakarta. The analysis of the current urban situation includes the physical characteristics of existing urban patterns, utility, and public facilities. Finally, the paper summarizes the most current urban issues facing the residents, which contributes to making the best decision to develop these settlements.
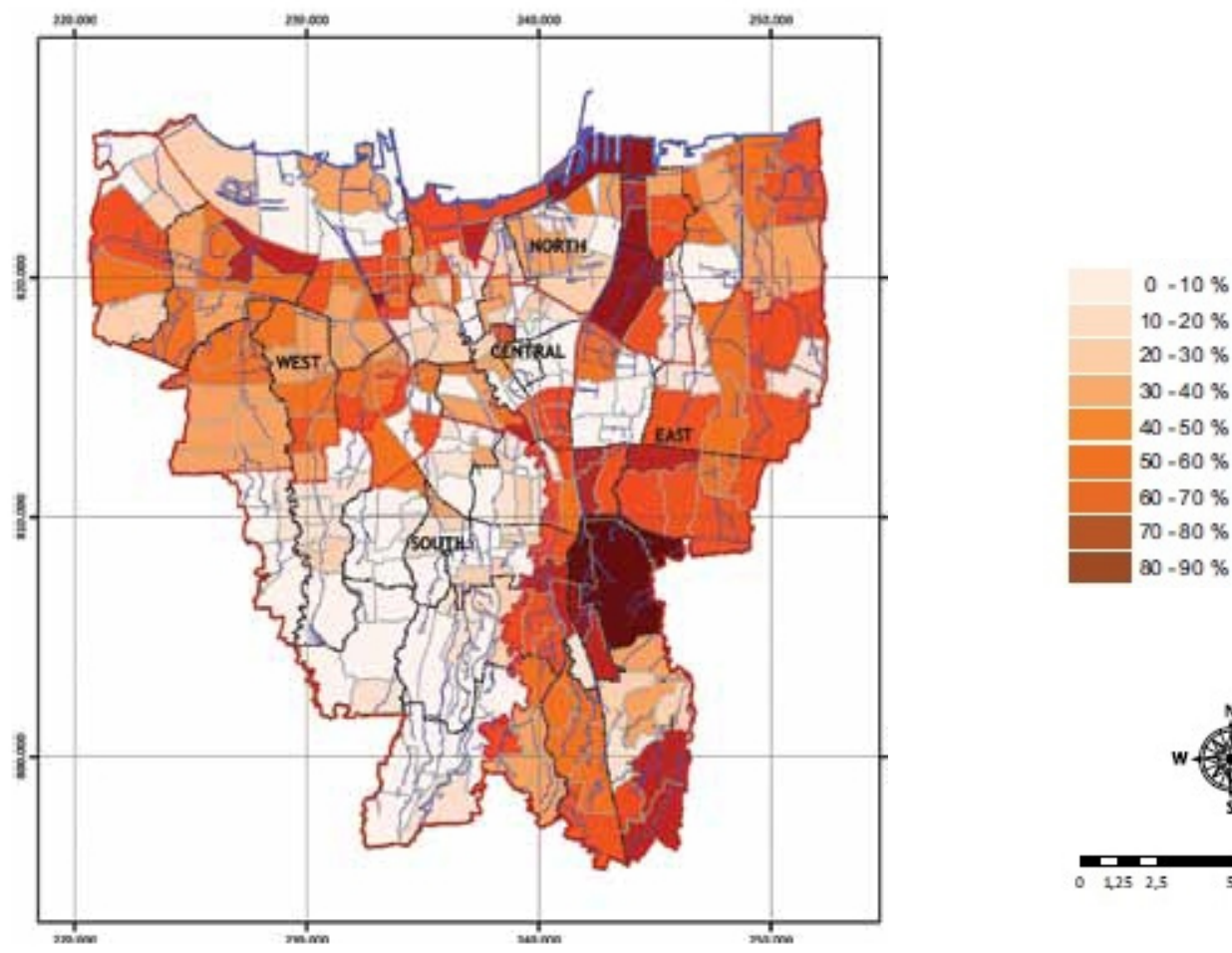

Figure 1. The percentages of unregistered land in Jakarta

Source: (Baker, 2012, p. 20).

\section{Urbanization in Jakarta}

Jakarta is the one of the largest metropolitan in Southeast Asia with great rate of population growth and rapid urbanization. The city has been the focus of economic activity that has attracted many immigrants from the countryside and neighboring cities, which have settled over previous decades. This growth contributed to urban expansion at the expense of agricultural land and high demand for housing over the past two decades. The rapid urbanization led to the emergence of multiple problems such as floods, traffic, poverty, and housing. Historically, Jakarta grew at steady growth rates until 1945. In the early 1960s, the city began urbanization and population growth due to mass migration of rural migrants to improve economic conditions. As shown in Fig.2 Jakarta's population jumped from 4.5 million in 1970 to more than 10 million in 2017. In addition, the annual migration has been estimated at 250,000 (WorldBank, 2011). Population growth rates in the period from 2000 to 2010 exceeded $7 \%$. However, this growth rate of the area exceeded government estimates, which was $1 \%$ from the 
same period. The population of Jakarta is spread over five major municipalities: Central Jakarta (Jakarta Pusat), West Jakarta (Jakarta Barat), South Jakarta (Jakarta Selatan), East Jakarta (Jakarta Timur), and North Jakarta (Jakarta Utara). As shown in Table 1. North Jakarta has approximately 1,729,444 inhabitants or about 17.16 percent of total population of Jakarta. According to the government's statistical data, 27\% of North Jakarta's residents are poor (DKI-Jakarta, 2011). Moreover, the proportion of residents in informal settlements exceeds $11 \%$ of the total population in North Jakarta (Baker, 2012).

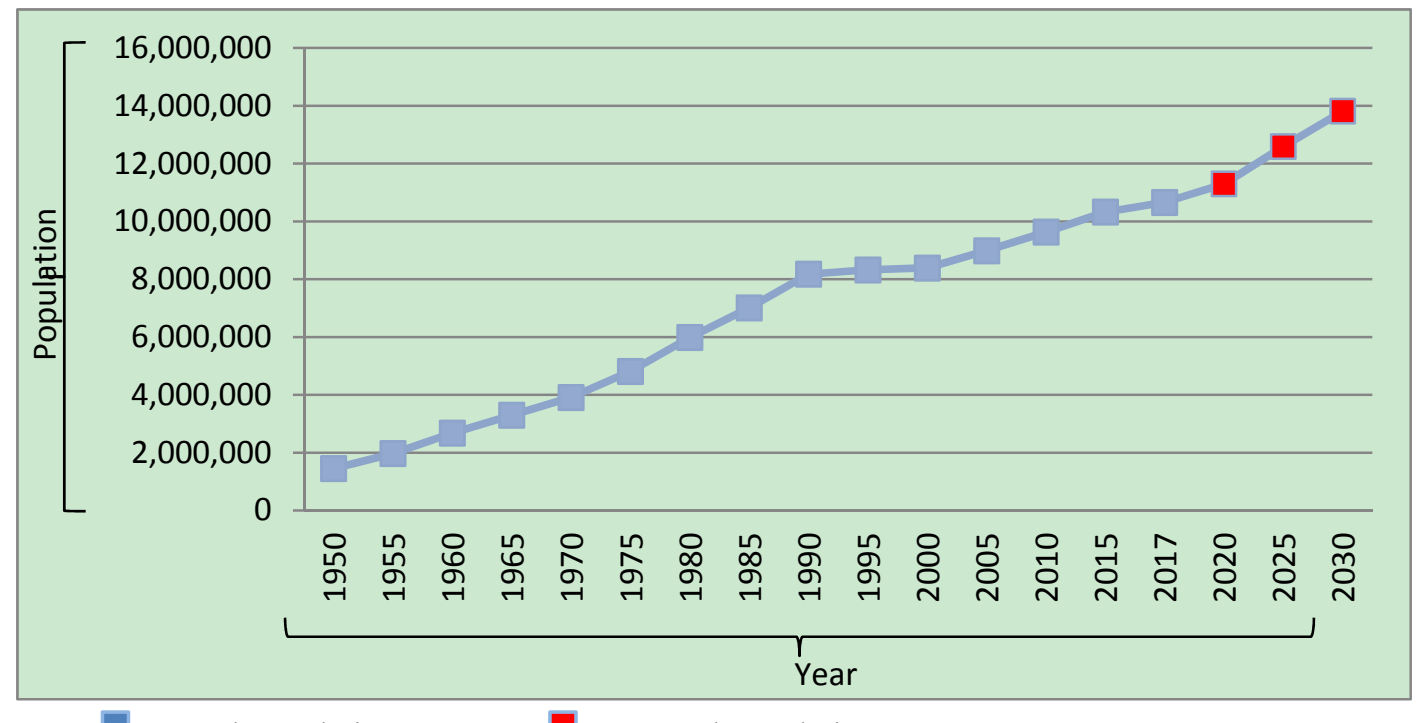

Actual population

Expected population

Figure 2. The stages of population growth in Jakarta

Source: (Worldpopulationreview, 2017).

Table 1. Demographic breakdown of Jakarta

\begin{tabular}{clcccc}
\hline No. & Urban Area & Population & $\begin{array}{c}\text { \% Pop. in informal } \\
\text { settlements }\end{array}$ & Area $\left(\mathrm{km}^{2}\right)$ & Density \\
\hline 1 & Central Jakarta & 910,381 & $0.44 \%$ & 48.13 & 18,915 \\
2 & West Jakarta & $2,430,410$ & $0.96 \%$ & 129.54 & 18,762 \\
3 & South Jakarta & $2,164,070$ & $0.83 \%$ & 141.27 & 15,319 \\
4 & East Jakarta & $2,817,994$ & $0.84 \%$ & 188.03 & 14,987 \\
5 & North Jakarta & $1,729,444$ & $11.56 \%$ & 146.66 & 11,792 \\
6 & Thousand Islands & 23,011 & - & 8.7 & 2,645 \\
& Total & $10,075,310$ & - & 662 & 15,22 \\
\hline
\end{tabular}

Source: Author according to data from (Jakarta, 2014).

* Percentage of population in informal settlements from: (Baker, 2012, p. 21).

Fig. 3 shows the comparison of the stages of urban sprawl in Jakarta. Since 1976, the population growth has reached more than 5 million people, and the growth of urban areas at the expense of agricultural and natural land is observed until 2004. Economic growth has had significant impacts on the social, cultural and environmental sectors over the past decades (Prasetyanti, 2015). However, this expansion has had negative consequences for the provision of housing, utilities and employment opportunities (Miller et al., 2012). Unregulated urbanization has led to the shortage of land supply and high land values. Moreover, urban economic opportunities are lower than the expected growth rate of urban labor force. Therefore, many workers and low-income immigrants are unable to afford the cost of housing within the urban boundaries of the city. As most of the immigrant groups are low-income people, they have settled into groups of area that are often located in uninhabitable areas or far from developed areas (Damayanti \& Kossak, 2016; Prasetyanti, 2015). The poor have no choice but to live in kampung which below the healthy residential environment. 


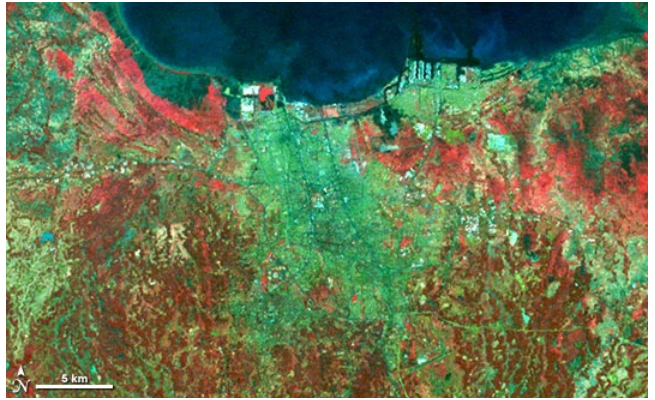

A. Satellite image of Jakarta in 1976

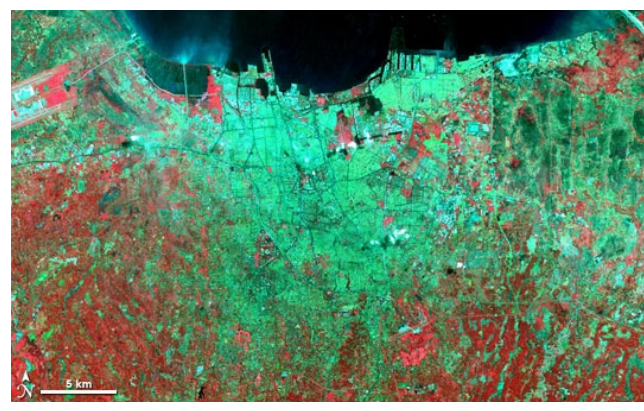

B. Satellite image of Jakarta in 1989

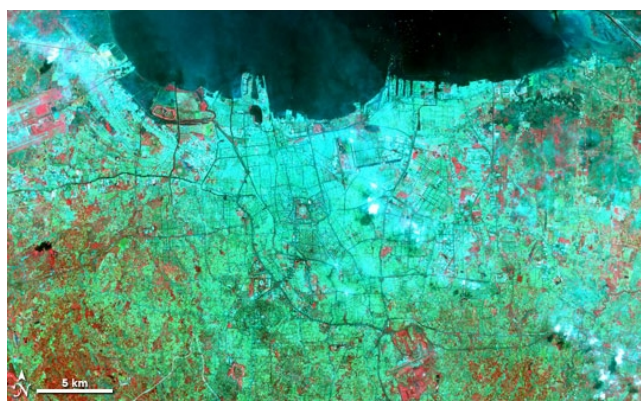

C. Satellite image of Jakarta in 2004

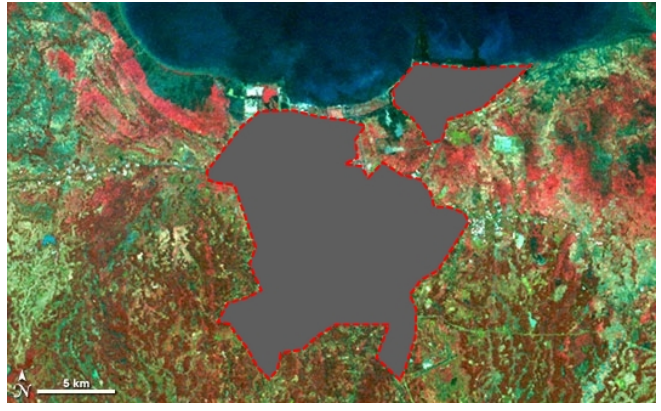

Urban growth in 1976

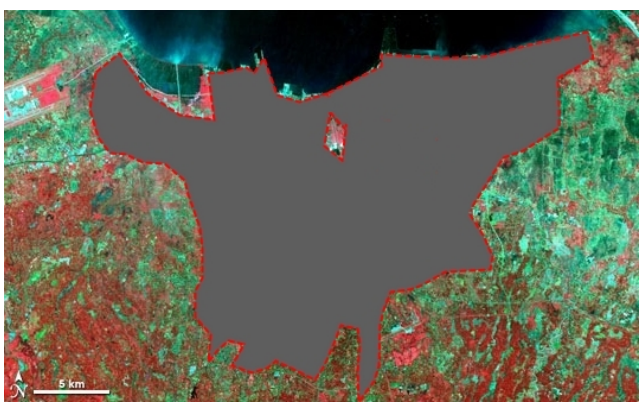

Urban growth in 1989

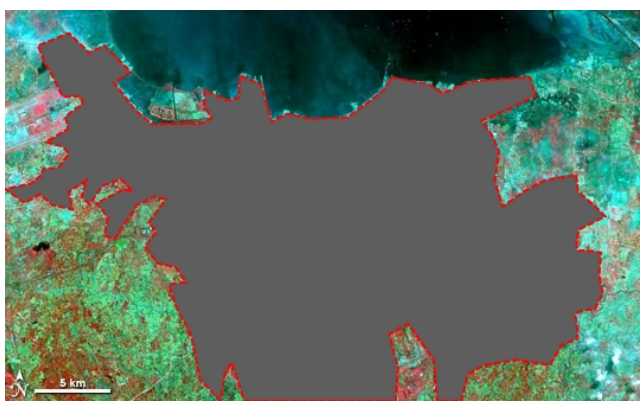

Urban growth in 2004

Figure 3. Stages of urban sprawl in Jakarta

Source: (NASA, 2005).

\section{Analysis of Urban Policies}

The policies of dealing with the kampung in Jakarta have evolved according to four main directions, including immigration control, slum clearance, resettlement projects, and urban upgrading. The government focused on subsidizing low-cost housing and setting up public housing projects to absorb the poor and improve their livelihoods. Since 1969 The government has developed a multiple five-year plans to improve the kampung which called The Kampung Improvement Program KIP (UN-Habitat, 2006). The KIP were funded by the government, the World Bank, and NGOs. The central government has assumed the responsibilities of technical consultation and financial support, while the local government has assumed responsibility for designing and implementing the plan (Djajadiningrat, 1994). The program aims to improve the living conditions of kampung residents and support their economies. The KIP focused on urban upgrading in kampung by providing 'minimum' basic services and improving the current environment. As shown in Fig. 4 the program has prioritized urban improvement through eligibility criteria including the age of kampung, flood-prone sites, sanitation and population density (Nurdiansyah, 2018). 


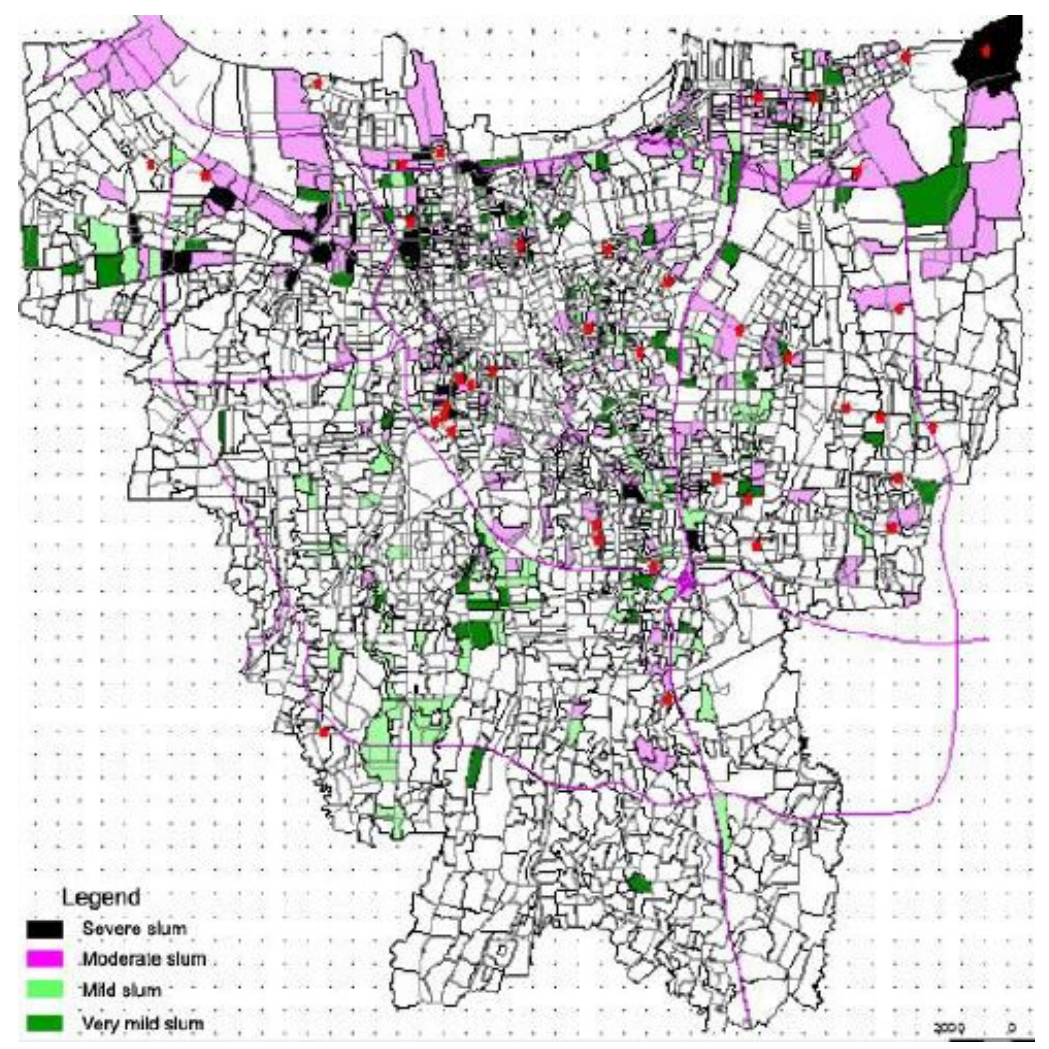

Figure 4. Kampung proliferation in Jakarta based on deterioration criteria

Source:(DKI-Jakarta, 2010).

The KIP included improvement of vehicle roads, paving of pedestrian roads, waste control, provision of public drinking water (public taps), sanitation, public toilets, clinics and schools (WorldBank, 1995). The program has also implemented a number of resettlement projects aimed at relocating residents to new urban environments. These projects have been resisted due to lack of suitability for residents' needs (UN-Habitat, 2003). As shown in Fig.5 the urban policies of kampung have contributed to the reduction of the level of urban deterioration, where statistics indicate the number of degraded areas in Jakarta was 392 in 2011. However, this number has been reduced by $43 \%$ in 2013. Finally, the KIP do not provide sustainable mechanisms for urban improvement. The proposed improvements require maintenance in the future, financial funding, and greater community dependence on the government (Supriatna \& Molen, 2014). 


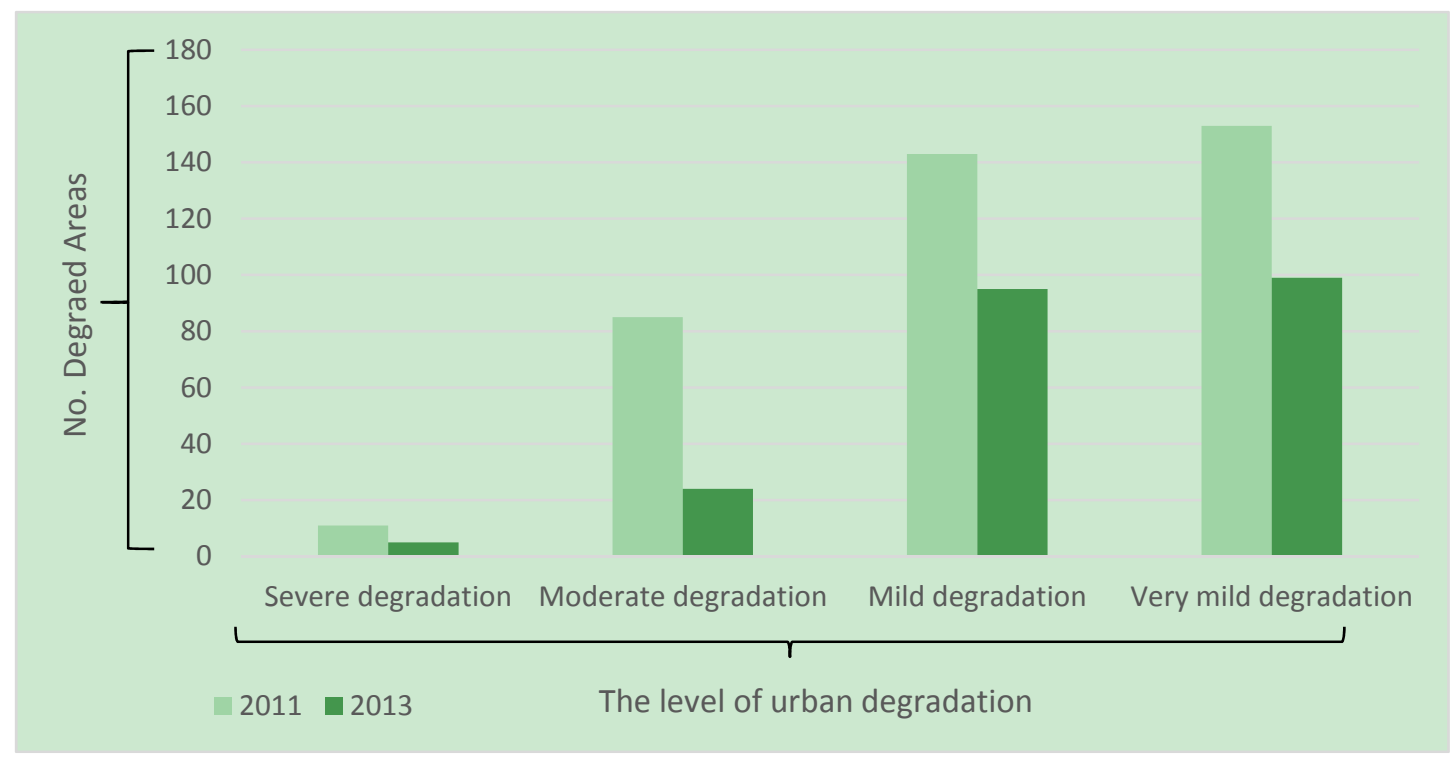

Figure 5. The urban status of degraded areas during 2011-2013 in Jakarta

Source: (BPS, 2013).

\section{Methodology}

This paper adopts descriptive and comparative analysis of three case studies in North Jakarta. As shown in Fig. 6 a plan is devised to determine the location of these case studies: A. Kampung Bandan; B. Kampung Luar Batang; and C. Kampung Muara Baru. The grade of settlement is based on a classification system by the Bureau of Statistics measuring the number of poor housing, the quality of water and sewer, density, water sources, and the location of area. These cases were selected based on their poor urban classification, where statistics show that the largest concentration of the poor is North Jakarta by $11 \%$ of $1,729,444$ (Baker, 2012). The pre-data collection is prepared as required to determine the quality of the data and the purpose of the study. Secondary data were prepared by reviewing national urban policy reports and population data. Several reviews have been conducted on past research, including methods for improving informal settlements and their urban issues. There is a lack of statistical sources about the kampung due to they are not officially registered. In addition, the government has used varying or conflicting methodologies to defines poverty or slums (McCarthy, 2002). Primary data was collected to analyze the urban status in three settlements, based on field photography, observation, and investigation with residents. The five-day field visits focused on recording visual observations such as urban degradation, building materials, road patterns, urban blocks, and the state of public utilities. Furthermore, many observations were made on economic and social activities such as hawkers, leisure activities, and mobility. A simple random sample was used to determine the representative sample of the community. Questionnaires were distributed to 60 residents in three informal settlements. The distribution per settlement was $45 \%$ for Kampung Bandan, 25\% for Kampung Luar Batang, 30\% for Kampung Muara Baru. These rates were determined based on the density and size of the settlement to achieve fair representation and impartiality. Questionnaire was designed to clarify three main parts that measure the urban status from the perspective of the residents. They were asked to rank the most important urban issues of the physical structures, utility, and services. Residents were able to prioritize these characteristics based on their daily needs. 


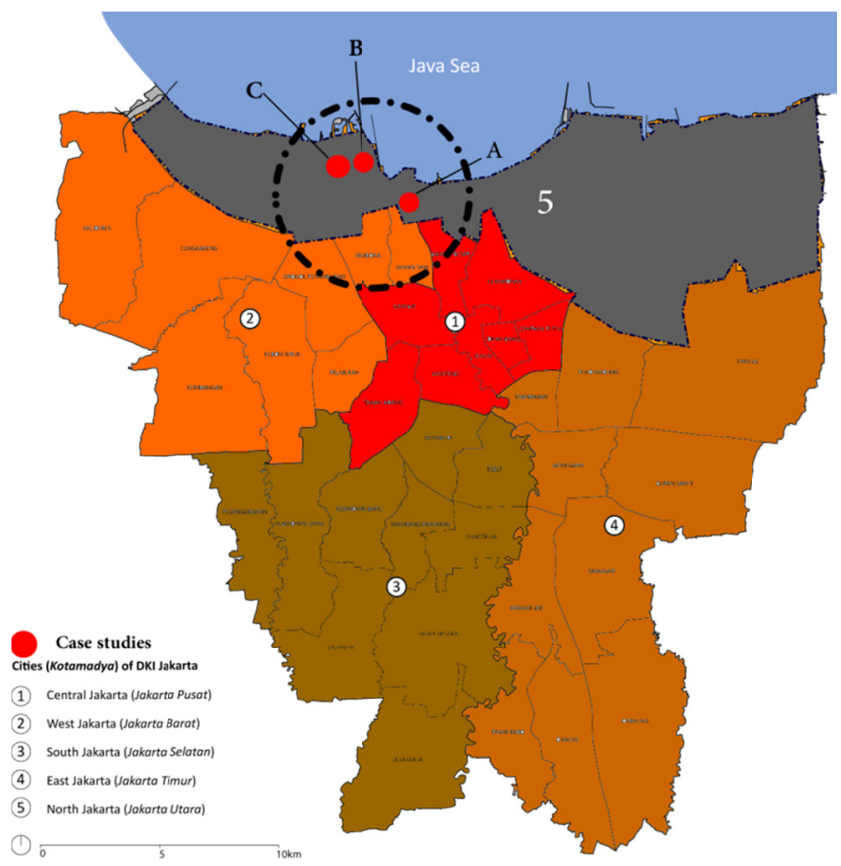

Figure 6. Site of case studies

Source: (Rochelimit, 2009) modified by the author.

Direct observation was used to validate responses on visual features of study cases such as structural density, state of buildings, public spaces, and facilities condition. The challenge in field surveys was to communicate with residents orally to clarify some of the urban problems they face in their settlements. Therefore, translators were hired to translate from local language into English. To analyze data, descriptive and comparative analysis was used to describe the urban characteristics of informal settlements, which include their physical state, utilities, and public facilities. As shown in Fig. 7 descriptive analysis helps to answer the question: how can one understand the urban characteristics of these settlements? Moreover, this method summarizes the overall priorities of the urban issues for these settlements as statistical tables and graphs. Comparative analysis used to assess the current status of informal settlements through comparing the views of the residents in three different cases. Statistical Package for the Social Sciences (SPSS 17.00) is used to compare the respondents' views in the three cases. Finally, Fig. 8 summarizes analytical framework of this paper.

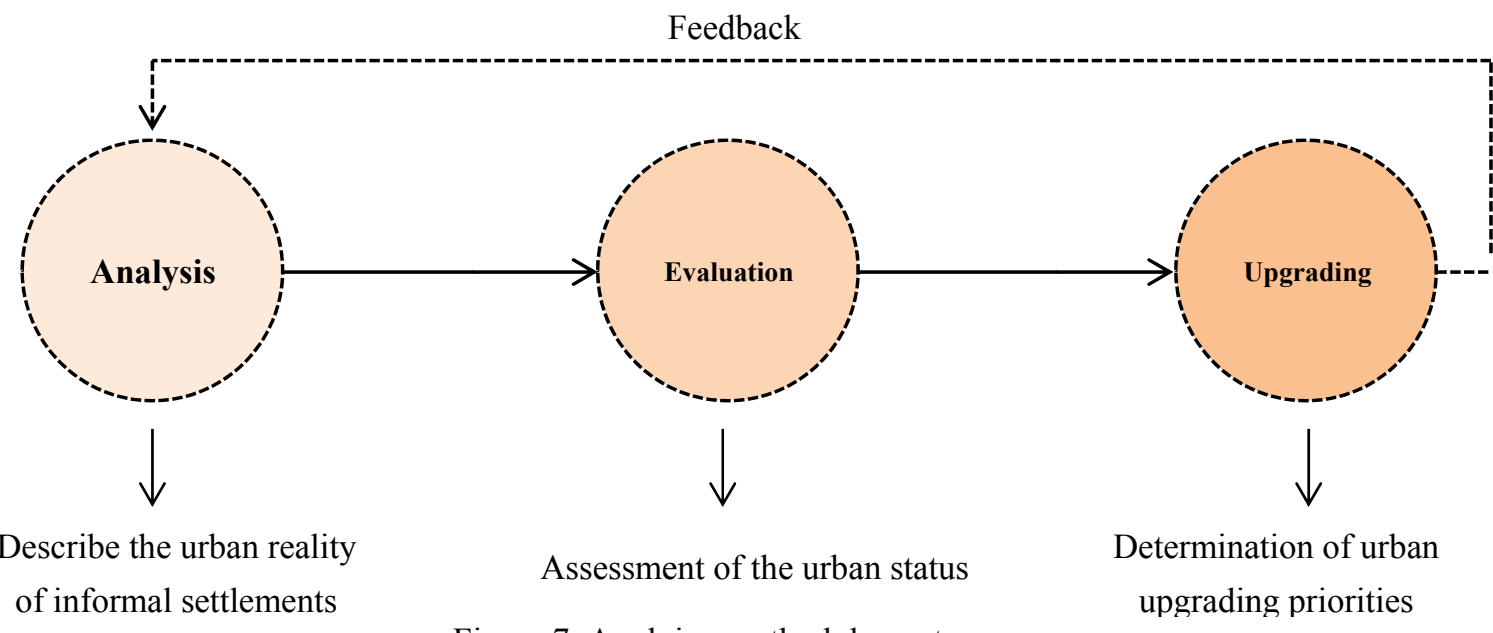

Source: The author.

Figure 7. Applying methodology stages 


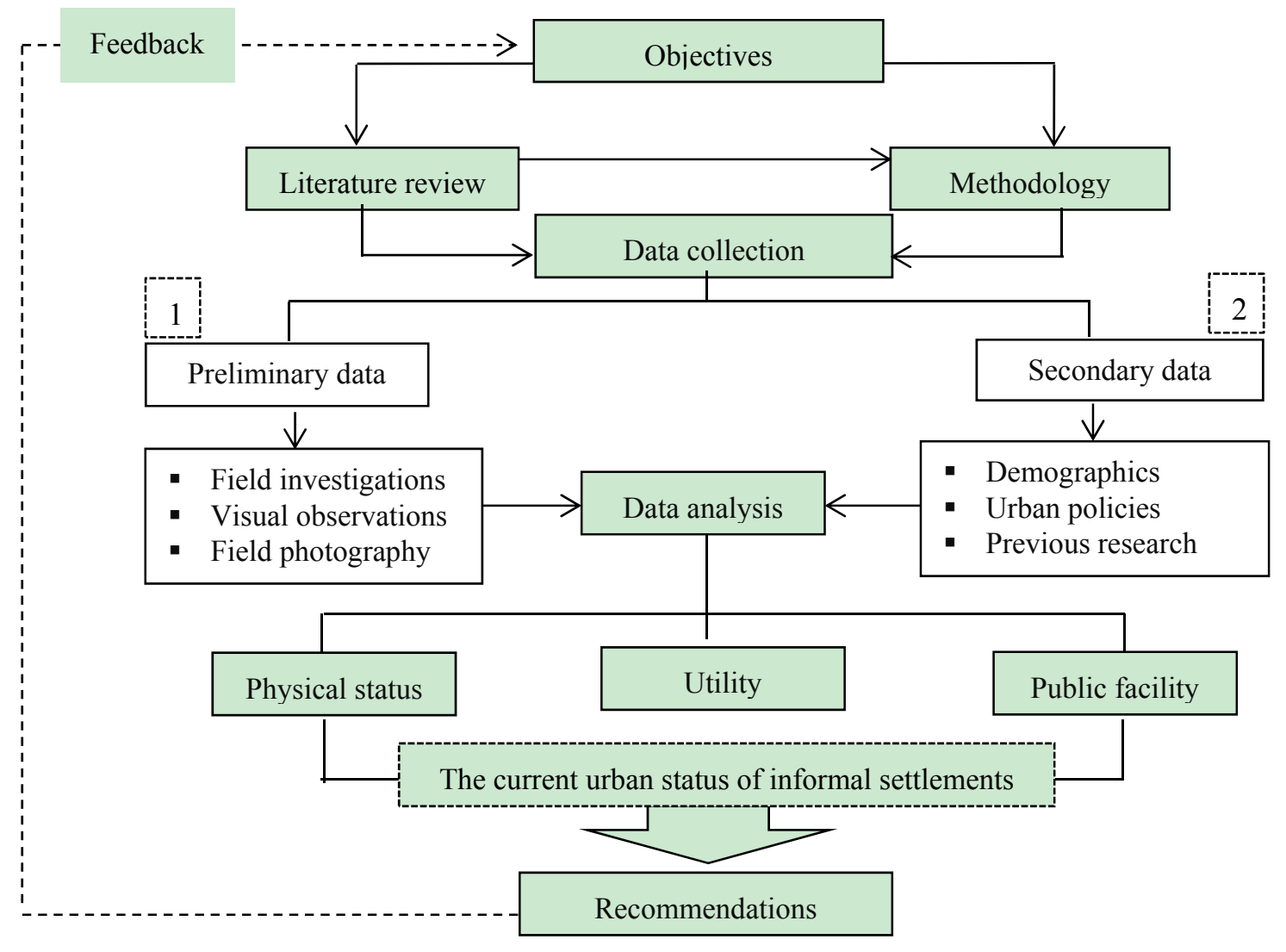

Figure 8. Analytical framework

Source: The author.

\section{The Concept of Informal Settlements}

According to UN-Habitat (2015), informal settlements are residential area that lack basic service infrastructure, do not comply with planning regulations, and are often located in dangerous environments. They have been developed without legal claims or have been occupied illegally (Srinivas, 2013). This term refers to illegally built areas, including "spontaneous", "unauthorized", "unplanned", "illegal" or "squatter" settlements (Surveyors \& Europa, 2015). In addition, these settlements can be built on planned or unplanned areas but without official approval (Ali, 2006). The term "informal" may be use for "settlements of refugees or vulnerable people overcrowded, and dilapidated housing in cities, or slums" (Surveyors \& Europa, 2015, p. 18). Therefore, these settlements do not comply with the requirements of health, environment, ventilation, lighting, and building regulations (Lombard, 2016).

Informal settlements are one of the community's efforts to overcome the problem of affordability. However, these efforts are not subject to planning standards such as structural density, road networks, and facility distribution (Alzamil, 2011). Informal settlements are determined by their 'legal status' and the 'physical condition' of residential buildings. Thus, 'legal status' is used to denote construction on land that does not have formal planning approval through illegal land occupation such as 'squatters' or illegal transformation of land use from non-residential to residential use such as 'semi-informal housing'. However, 'physical condition' refers to the quality of the residential environment which includes the urban fabric, construction safety, construction materials, building height, access to clean water supply, electricity, and sewage systems. As a result, the concept of informal settlements do not conform to the principle of adequate housing, which is "the right to live somewhere in security, peace and dignity" (Pellissery, Davy, \& Jacobs, 2017, p. 18). Moreover, these settlements do not comply with human rights law which states "Everyone shall have the right to live in a healthy environment and to have access to basic public services" where people are not protected from forced eviction (Olawuyi, 2016, p. 212). 


\section{The Causes of Informal Settlements}

Jibril (2006), and Fernandes (2008) stated that rapid urbanization and population growth in cities are two of the causes of informal settlements. Population growth occurs as a result of internal migration to major cities because of a lack of facilities in small towns and rural areas. Therefore, population growth contributes to an increased demand for housing. Low-income people become unable to obtain adequate housing within the framework of financial capacity due to housing costs, increased demand, and a lack of housing supply. However, Napier (2002) believed that there is no relationship between urbanization and informal settlements. Napier (2002) found that some countries have equal proportions of informal settlements such as Burkina Faso 12.4\%, Congo 11.8\%, and South Africa 11.6\%. However, these countries have varying levels of urbanization (Napier, 2002). Dumashie (2004), and Mata (2013) stated that there is a direct correlation between the poverty rate and the proliferation of informal settlements. International organizations indicate that poverty rates are the highest in the world in Africa, where the percentage of the population living below the poverty line (below US\$1 a day) in Sub-Saharan Africa is $46.3 \%$, compared with all of the poor regions in the world (Napier, 2002, p. 5). The population distribution of the poor in Africa is often concentrated in degraded areas and informal settlements that suffer from a lack of services, health, sanitation, and utilities (Napier, 2002).

Jibril (2006) and Potsiou (2010) stated that civil wars and political instability lead to the forced evacuation of populations to other areas in search of safety and stability, as is occurring today in Syria, Iraq, and Yemen. Gabriel (2007) noted that civil wars and political instability are two of the main reasons for the spread of informal settlements in some countries of Eastern Europe, such as Albania, Croatia, the Republic of Macedonia, and Bosnia and Herzegovina. The civil wars coincide with economic recession and weak state institutions. Therefore, the spread of many informal settlements has occurred as a reaction to absorb the large population displacement (Gabriel, 2007). Furthermore, Dumashie (2004) reported that civil wars and political instability play an important role in the emergence of informal settlements in Africa. For example, Mozambique suffered from a recession of economic activity, poor infrastructure, and poverty. These factors arose as a reaction to political changes, civil wars, and a lack of economic resources (Dumashie, 2004).

Urban planning policies in developing countries have failed to achieve sustainable development that brings justice and equality to the segments of society. In most developing countries, land management policies do not take into account the economic diversity of the population (Tsenkova, 2009). Mata (2013) stated that in Brazil, the division of land laws contributes to the increasing cost of land. Housing laws impose a minimum land area of $125 \mathrm{~m}^{2}$. Low-income households are unable to meet these standards due to an inability to bear the cost of land. Therefore, informal housing has become a popular option to address the economic ability of low-income households. Jibril (2006) noted that the housing market suffers from government bureaucracy, slow implementation of projects, and complex government procedures. Land development in Third World countries is subject to lengthy bureaucratic procedures for approval. These bureaucratic procedures encourage developers to resort to informal land markets.

\section{Characteristics of Informal Settlements}

Urban characteristics of informal settlements vary from state to state depending on the economic situation, social conditions, and the surrounding environment. Informal settlements are described as marginalized areas of education, health, and well-being. They are characterized mostly by deteriorating houses and a lack of adequate infrastructure, sewerage, and drainage (Soliman \& de Soto, 2004). Its population suffers from many social problems such as drugs, crimes and violence (UN-Habitat, 2012a). These settlements do not comply with building regulations in cities because they are built on informal land. Furthermore, families live in unhealthy conditions that do not meet minimum standards of quality and structural integrity. They often live in temporary structures or dilapidated and overcrowded units with more than 5 people share a single room for sleeping, cooking, and living (UN-Habitat, 2003).

A lack of tenure security is a main characteristic of informal settlements, which is typically not registered in official property records and violate building permits (Galbreath, 2007). Land tenure security is key factor that influencing housing sufficiency and affordability (UN-Habitat, 2011). The lack of tenure security is a major challenge for governments to improve these settlements, where most of occupants do not have an official document that confers occupation to the land. Therefore, most of these settlements are built on dangerous or unsuitable lands such as flood waters, industrial plants, or landfills (UN-Habitat, 2003). In Africa and South America, tolerant housing policies have contributed to the stability of poor households in informal settlements without threat of forced evictions. In contrast, rapid economic growth and urbanization in Asian cities have contributed to supporting forced evictions policies of the inhabitants of these settlements (Takahashi, 2009). 
Access to serviced land for housing is one of the major problems faced by majority Asian cities (UN-Habitat, 2011, p. 34). These settlements suffer from a lack of sanitation and potable water sources, waste collection systems, electricity supply and rainwater drainage (UN-Habitat, 2003). Napier (2002) stated that the population distribution of the poor in Africa is often concentrated in informal settlements that suffer from a lack of services, health, sanitation, water supply, electricity, and sewage disposal.

Urban fabric in informal settlements is described as irregular pattern. Households use the maximum amount of space in construction, which negatively affects the level of lighting and ventilation. Therefore, the proportions of urban blocks are increasing at the expense of public spaces and green areas within those settlements (UN-Habitat, 2013). As shown in Fig. 9, the urban fabric is shaped by the people themselves who have no prior experience in the planning process and depend on the natural conditions of the site. Finally, building materials in these settlements usually vary depending on the residents' economic status. In some cases, they are built of durable materials such as concrete, brick, and wood. In contrast, there are some temporary houses built of cardboard, tin, and reclaimed materials (Soliman, 1996).
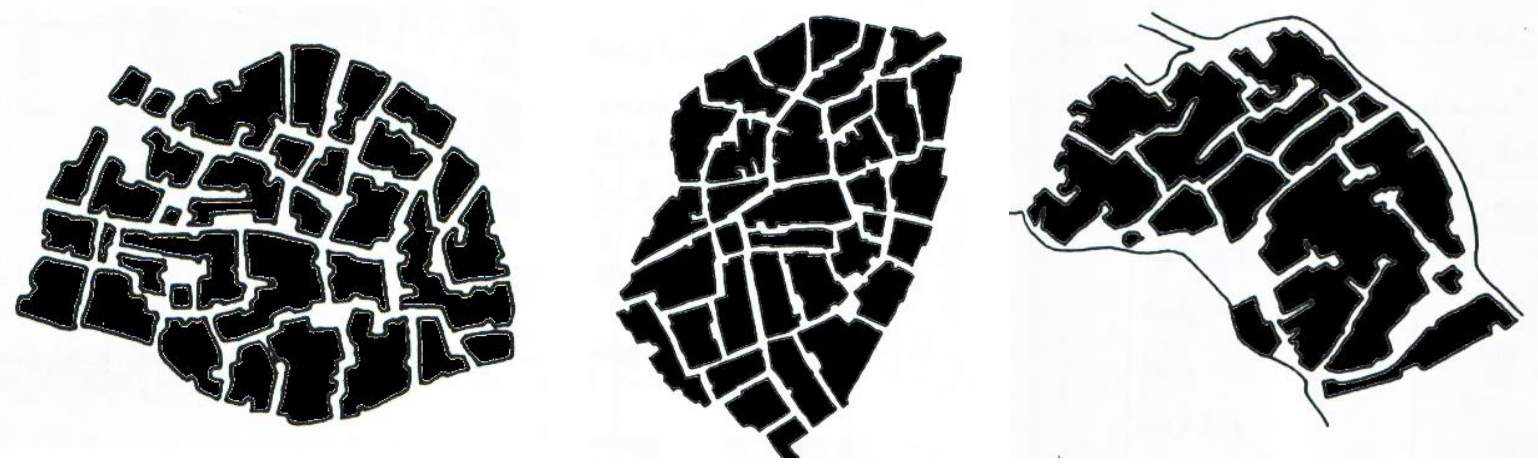

Figure 9. Styles of urban fabric of informal settlements

Source: (Soliman, 1996) modified by the author.

\section{Strategies of Addressing Informal Settlements}

Since the end of the 19th century, urban planners have been looking to improve living conditions and promote social values through optimal design of human settlements (Gillette, 2012). Although informal settlements may be appear as housing issue, but they have many economic, social, environmental and legal implications. Strategies for dealing with informal settlements have varied to include removal, partial development, resettlement, urban rehabilitation, upgrading and improvement (Minnery et al., 2013). Some of these strategies dealt with the physical side only, while some strategies were taken into account with socio-economic dimensions. In general, these strategies include two principles: forced eviction or on-site improvement (Turok, 2014).

The first way adopts removal and redevelopment due to that informal settlements are uninhabitable urban environments with many manifestations of pollution and social deviations. The removal of informal settlements contributes to the elimination of urban deterioration, but it has many economic and social consequences. This manner leads to the displacement of many low-income and restructure the lifestyles of residents. However, it is often accompanied by destruction of the social and economic environment of residents which leads to the emergence of new informal settlements. Many urban policies in developing countries have adopted the principle of eliminating informal settlements without compensating residents with housing alternatives that suit their economic conditions and achieve access to their workplaces.

The second ways adopts legitimizing and improving informal settlements as they represent opportunities for low-income housing. In recent years, the strategies of dealing with informal settlements have been transformed from removing urban structures into improvement and upgrading. Given the lack of land supply, this strategy is effective in maintaining infrastructure and social networks (Werthmann \& Beardsley, 2008). These strategies seek to transform the poor into a better quality of life through community empowerment programs. The development of these settlements contributes to economic benefits for the poor to meet their basic needs. Moreover, the upgrading of informal settlements contributes to the integration of urban communities within the urban context (Prasetyanti, 2015).

In Egypt, the number of people living in informal settlements is estimated at $6,465,905$, constituting $40 \%$ of the population of Greater Cairo (Abouelmagd, 2011). Informal growth emerged as a result of rapid urbanization and 
poor management of urban development policies (Hegazy, 2016). Despite the government efforts have been made in the development of public housing to settle low-income families. However, the public housing project suffers from a lack of occupancy, where the occupancy rate reached during the thirty years only $50 \%$. In addition, the public housing project suffers from a lack of facilities, services, public transportation and located in an area far from Cairo. Public housing projects placed in high-rise buildings which contributed to the disruption of the socio-economic fabric and stigmatization of its residents (Abouelmagd, 2011). In fact, public housing projects were not suitable for low-income people as an alternative to informal settlement because they did not fit their needs.

In Brazil, since the beginning of 1980, methods of dealing with informal settlements have been transformed into urban improvement and upgrading as an alternative to demolition ways (Bueno \& Sedeh, 2011). The first step in dealing with the informal settlements in the city of Sao Paulo was to establish comprehensive databases on the current status of these settlements and to identify areas of danger and actual needs. The government has brought electricity, sanitation and clean water to support the stability of the population. The improvement plans adopted the principle of community participation by nominating a community leader to act as a mediator between the local population and the government (Bueno \& Sedeh, 2011).

Turner (2000) noted that housing policies should provide the regulatory framework and financing opportunities for the population to improve the their residential environment. Housing is not just residential units that carry physical values, but rather a comprehensive system and lifestyle that are influenced by social values and economic conditions. Therefore, the effective policy for dealing with the informal settlements is not to provide new low-income housing units, but by creating the best way to exploit the existing environment and the available tools to upgrading of those settlements. As shown in Fig. 10. local planning agencies can contribute to stimulating the population to improve the residential environment and infrastructure as an alternative resettlement projects, especially in the absence of financial resources (Turner, 2000).

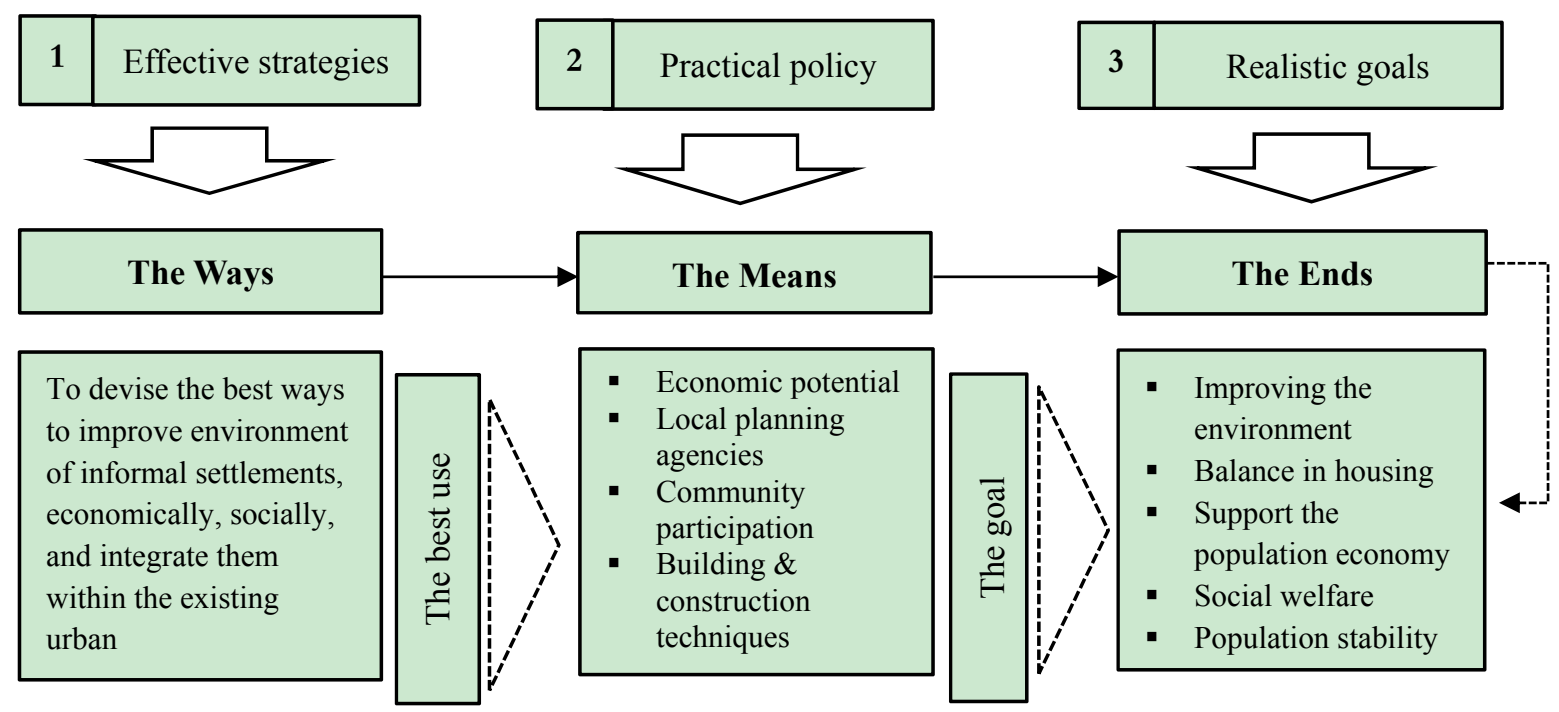

Figure 10. The principles of dealing with informal settlement

Source: Author based on (Turner, 2000).

Correa (2000) reported that informal settlement reflects the economic deficit and weak housing finance policies. Correa (2000) analyzed many cases of informal settlement in Asian cities such as Bombay, Dhaka, and Karachi. According to Correa (2000), the most challenge facing housing professionals is the difficulty of getting the proposed housing costs lower than what the population themselves are doing on their settlements. The inhabitants of these settlements use their own efforts and local resources to create simple and inexpensive urban structures. Therefore, solutions based on compensation will not provide residents with the actual cost of housing outside the framework of such settlements. In other words, projects to resettle populations in urban areas on the outskirts of cities are fail because they do not take into account the economic structure provided by these informal settlement (Correa, 2000). 


\section{Findings}

\subsection{Location and Socio-economic Characteristics}

Fig. 11 shows the locations of kampung cases in North Jakarta. Based on field visits most of kampungs in north Jakarta are occupied hazardous areas, adjacent to natural spaces, or close to urban landmarks such as railways, waterways, religious shrines, and land zoned for industry. These kampungs described as "densely populated, largely illegal, threatened, unserviced, low-income settlements" (UN-Habitat, 2005, p. 15). Residents of kampung often have homogeneous social cultures. They have their roots from the countryside and they maintain rural customs and traditions such as cooperation, neighborliness, and self-help (Djajadiningrat, 1994). In general, they are less educated than the average resident of other urban areas. The livelihoods of the residents are also linked to those areas, where they contribute to supporting the economy of the city. The residents often work as fishermen, security guards, scavenger, workers, food stalls, and small tokos (retail kiosks). Residents of kampung are characterized by mutual assistance or so-called 'Gotong Royong'. Mutual-help include cooperation in housing construction, financial support, and cooperation in daily living. It is a means of promoting social cohesion among the population that can be used in the development programs of these settlements (Djajadiningrat, 1994).
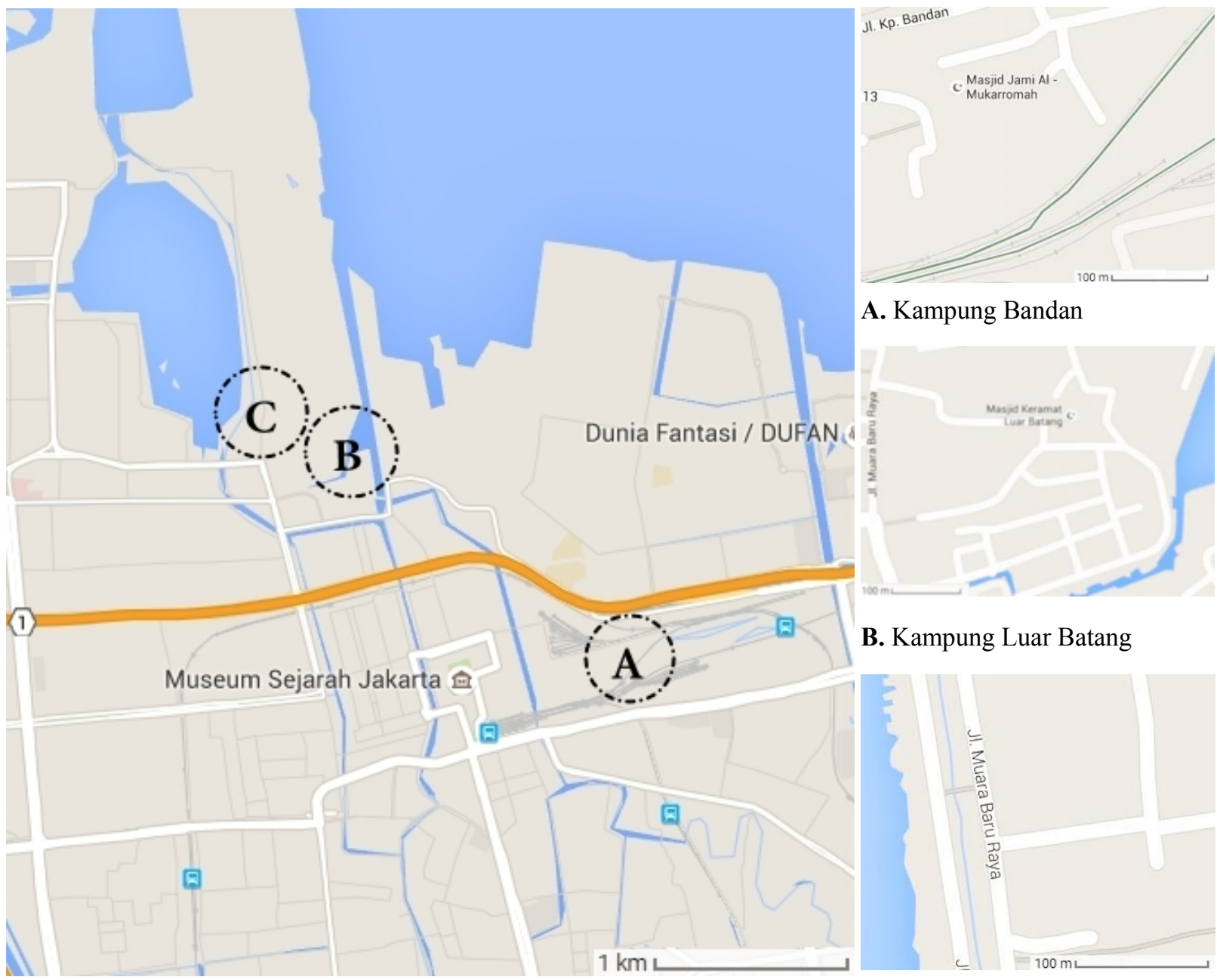

A. Kampung Bandan

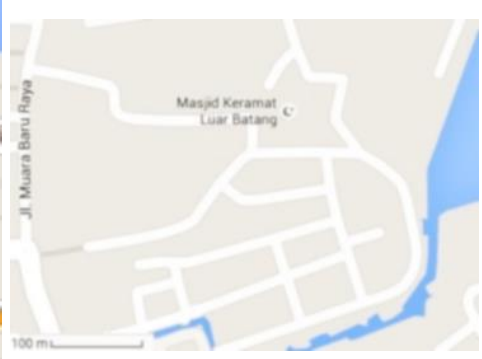

B. Kampung Luar Batang

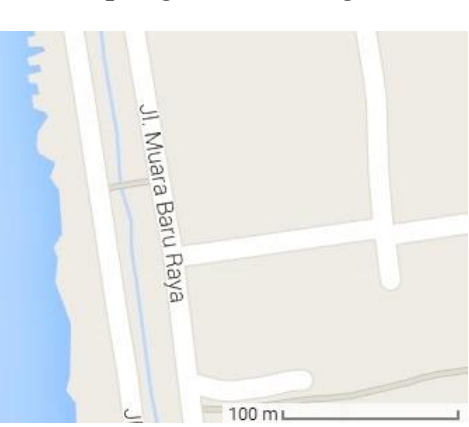

C. Kampung Muara Baru

Figure 11. The locations of the selected case studies in Jakarta Utara

Source: Google map, modified by the author.

\subsubsection{Kampung Bandan}

This kampung is a high-density area located close to Mangga Dua area at the border of North Jakarta and Central Jakarta along railway lines. This settlement is an urban complex of dwellings built of wood, iron or block in an 
unplanned manner. The area covers 11 hectares and is close to the Jakarta inner ring road at a distance not exceeding 0.5 kilometer. Residents build their homes within the buffer zone of the railway line which is dangerous for pedestrians and children. During rainfall, the area suffers from floods due to poor rainwater drainage networks, where the water level rises to more than 30 centimeters above ground level (Steinberg \& Bank, 2008). Moreover, the area is exposed to fire risks due to the random distribution of buildings and the quality of building materials. The last fire occurred on January 26, 2016 and destroyed more than 100 houses (Ibtimes, 2016). Most residents work as pedicab drivers, vendors of food products, and scavengers and use artificial strollers for transportation.

\subsubsection{Kampung Luar Batang}

This area is a deteriorating urban area located near the Ciliwung River estuary in North Jakarta, close to the Islamic shrine 'Al-Habib Husein bin Abubakar Allaydrus'. It covers approximately 9.5 hectares, where more than 10,000 residents live who mostly work in the industrial areas, on the Sunda Kelapa harbor, and are vendors of food products or fishers. This area has been a settlement for workers and fishermen since the 17th century. The population density is 684 persons per hectare (Subroto, 2006). The flood problem is one of the biggest issues facing this kampung because of the low level of the area from the sea. The urban fabric of this kampung includes organic narrow roads which do not allow for the movement of vehicles. Moreover, the area suffers from a lack of public spaces, infrastructure, especially water and electric transmission methods. The area has historic landmarks such as Luar Batang Mosque (or Masjid Luar Batang) which is important in guiding urban conservation policies to support tourism and improving the living and environmental conditions in the area.

\subsubsection{Kampung Muara Baru}

This kampung located at Baru, adjacent to Waduk Pluit which is an area prone to flooding in North Jakarta. The number of residents in this kampung is approximately 21,865 inhabitants who mostly work in the informal sectors such as vendors of food products, maids, becak drivers and fishers. Rapid population growth was due to the expansion of near harbor of fisheries which provided them with jobs (Zhua \& Simarmatac, 2015). The population density is 1,955 persons per hectare (Penjaringan, 2013). Residents build their dwellings informally on vacant land that owned by the state or neighboring companies (Zhua \& Simarmatac, 2015). The area suffers from flood risks, water supply, narrow roads, and poor drainage. This kampung has seen a number of floods for decades because it lies close to the coast. As a result, many residents adapt to these risks by raising housing units above the flood level. This unstable situation has enabled the city government to announce recently that residents should be evacuated elsewhere (Simarmata \& Entwicklungsforschung, 2015).

\subsection{Urban Fabric}

The formation of urban fabric in kampungs relied on self-effort in construction outside the framework of legislation and urban standards. Low-income families have sought to use maximum vacuums in building urban blocks. Fig. 12 shows a comparative analysis of the urban pattern of kampung cases. These urban patterns show isolation from urban environments and a notable lack of compliance with building regulations and health requirements. There is no uniform distribution of blocks among all of these kampungs. All of these blocks are irregular and tend to be semi-rectangular, linear, or semi-square. Main streets width range starts from 6 to 9 meters. However, the internal roads are very narrow, winding, and non-paved. They do not allow firefighters and emergency vehicles to access the area. In some parts, I noticed that the width of some roads do not allow the passage of more than two persons.

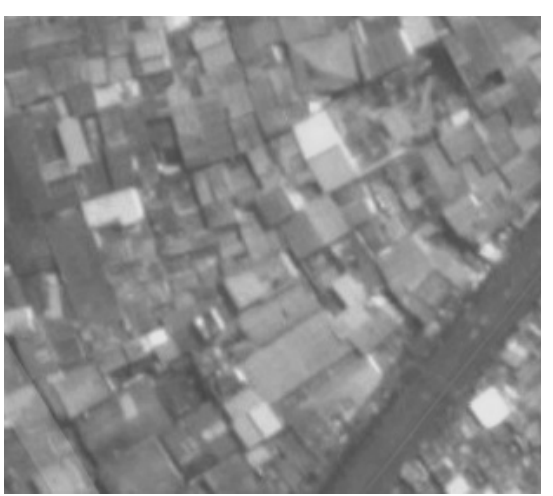

A. Kampung Bandan

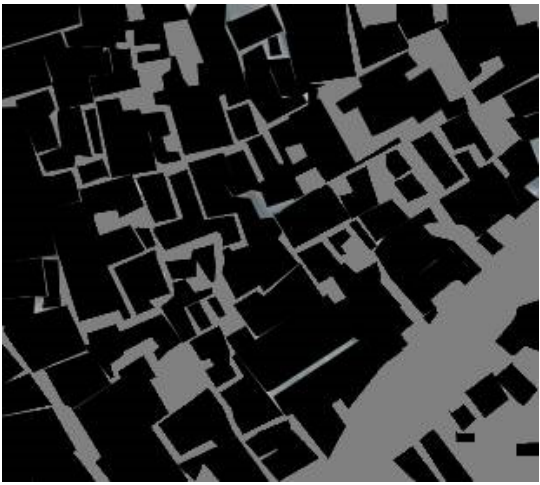

Semi-rectangular blocks

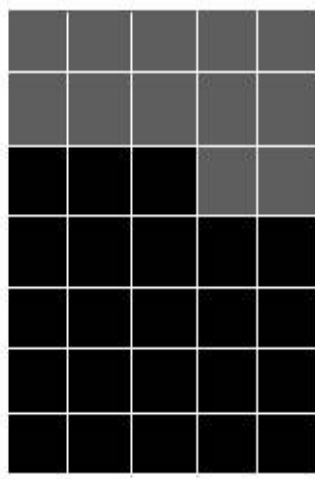

Built blocks 70\% 


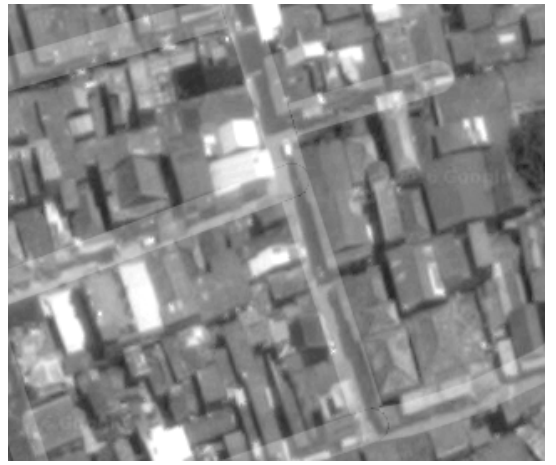

B. Kampung Luar Batang

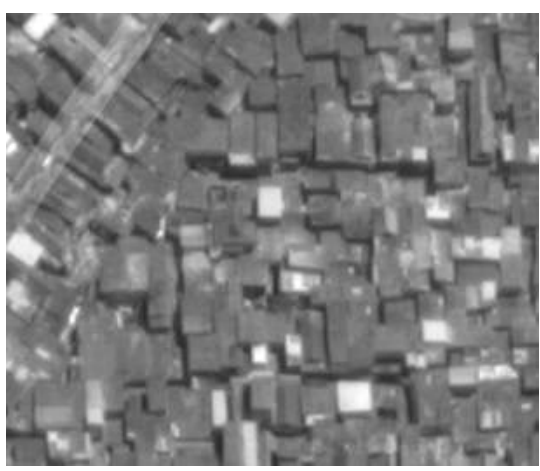

C. Kampung Muara Baru

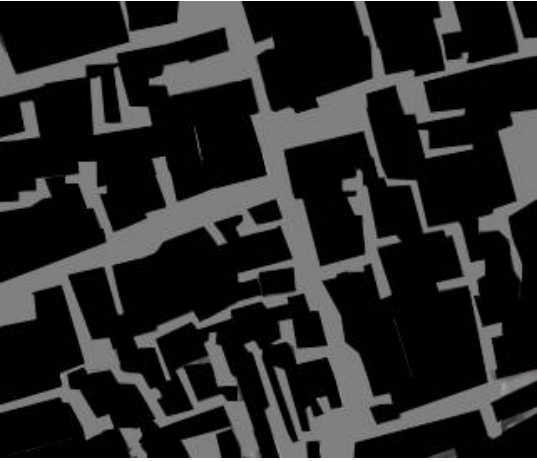

Linear blocks

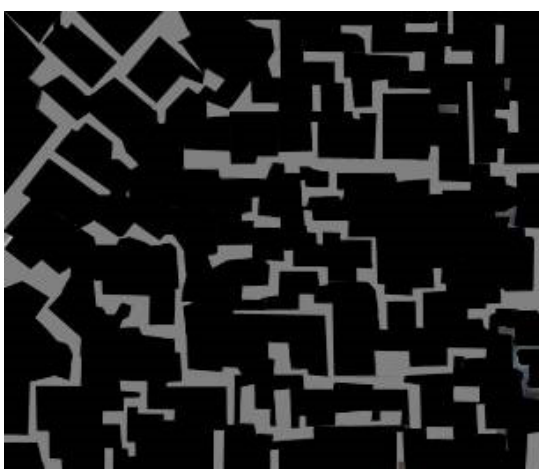

Semi-square blocks

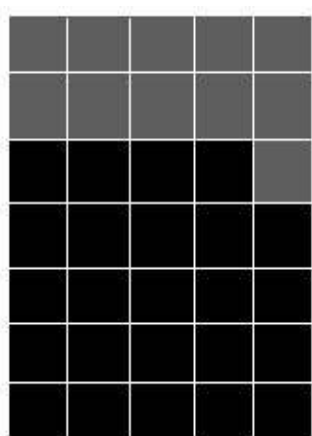

Built blocks $75 \%$

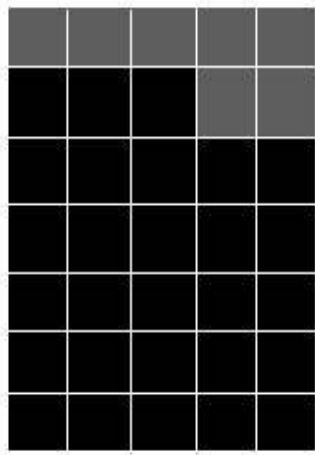

Built blocks $85 \%$

Figure 12. The samples of urban pattern of kampungs in Jakarta

Source: The author.

\subsection{Physical Status}

The current physical status of settlements do not comply with building regulations due to physical deterioration, variation in building materials, a lack of urban space and lighting and ventilation. Physical issues of these settlements are characterized by the contrast in building materials. As shown in Fig. 13 some houses have been built from reclaimed materials such as tin, cardboard and inorganic garbage piles. However, there are some houses built of durable materials such as brick, wood, and concrete. Nonetheless, they are incompatible with building regulations and environmental standards, such as inadequate lighting and ventilation. In fact, most of the residents in these settlements cannot afford to build adequate housing. Therefore, these houses are initially built from simple materials and then gradually altered according to the financial capacity of residents. There is a clear disparity in the height of buildings, where most buildings are detached or close to one another. This factor contributes to increasing structural blocks at the expense of urban spaces or landscape. However, the convergence between the blocks allows residents to build social relations and enhances their communication to cope with natural hazards. 

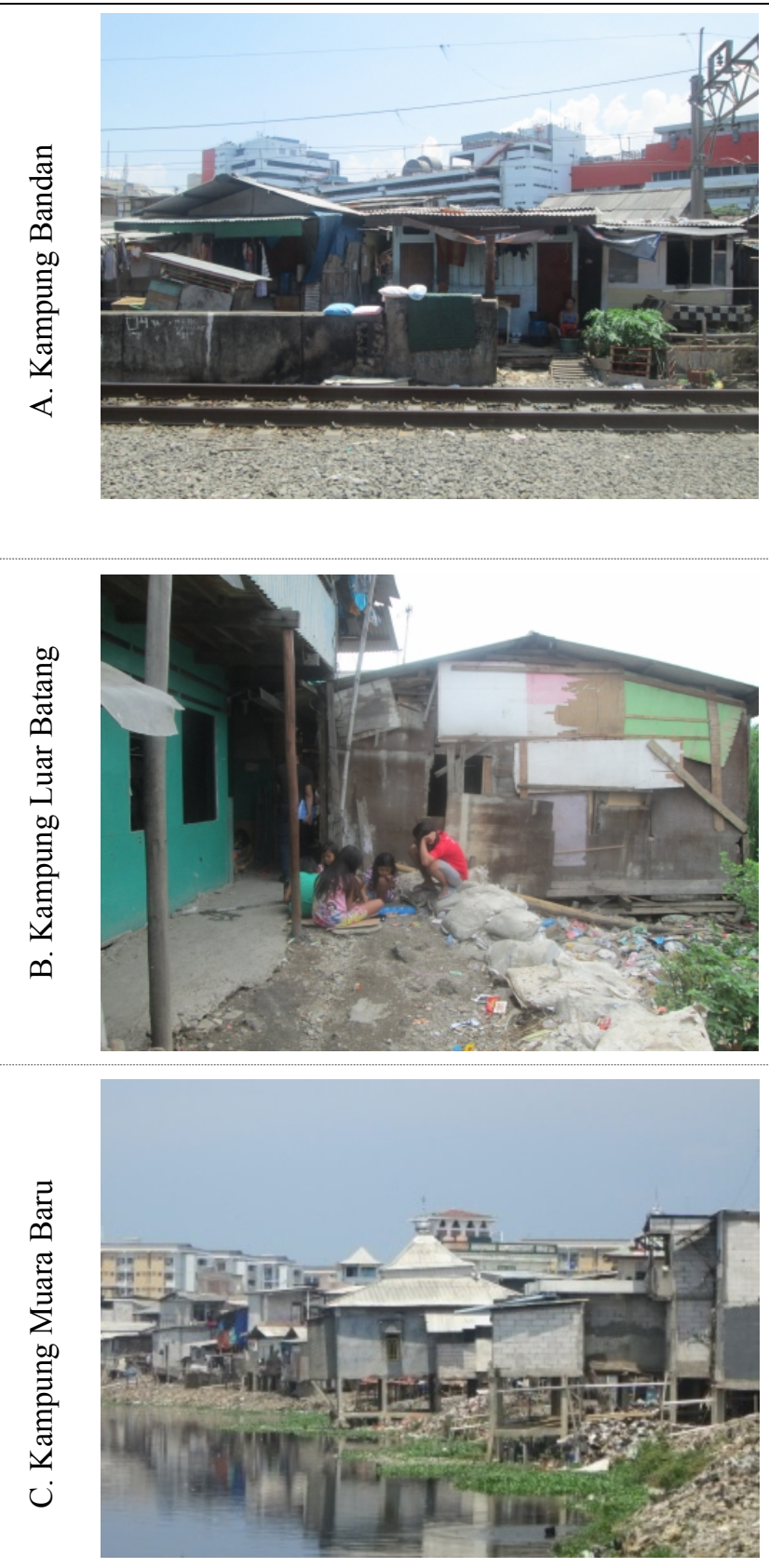

- Coordinates: $6^{\circ} 08^{\prime} 03.3^{\prime \prime S} 106^{\circ} 49^{\prime} 15.7^{\prime \prime} \mathrm{E}$

- Location: Housing units adjacent to the railway.

- Types of buildings: Permanent, semi-permanent, and temporary shelter.

- Buildings condition: more than $80 \%$ of the housing in a degraded state.

- Building materials: wood, iron sheets, and bricks.

- Potential risks: waste, fire, flood, water leak, pollution, smoke, noise.

- Coordinates: $6.124273^{\circ} \mathrm{S} 106.806969^{\circ} \mathrm{E}$

- Location: Housing units close to the water canal 'Ciliwung River'

- Types of buildings: Permanent, semi-permanent, and temporary shelter.

- Buildings condition: More than $70 \%$ of the housing in a degraded state.

- Building materials: wood, bricks.

- Potential risks: flood, waste, pollution, fire, water leak, smoke.

- Coordinates: 607'18.1"S 106²8'11.4"E

- Location: Housing units adjacent to the lake 'Waduk Pluit'.

- Types of buildings: Semi-permanent and temporary shelter.

- Buildings condition: More than $80 \%$ of the housing in a degraded state.

- Building materials: Bamboo for the houses' pillars, cardboard, wood, and plastic piles.

- Potential risks: flood, pollution, sinking, smoke, water leak, fire, waste.

Figure 13. The physical status of kampungs in Jakarta

Source: Field survey by the author.

Fig. 14 illustrates the current state of housing services in all of the kampung cases. Bathrooms inside the housing units are not available, and the residents use public baths for showers. However, some families use gallons of water to bathe their children inside the house. 


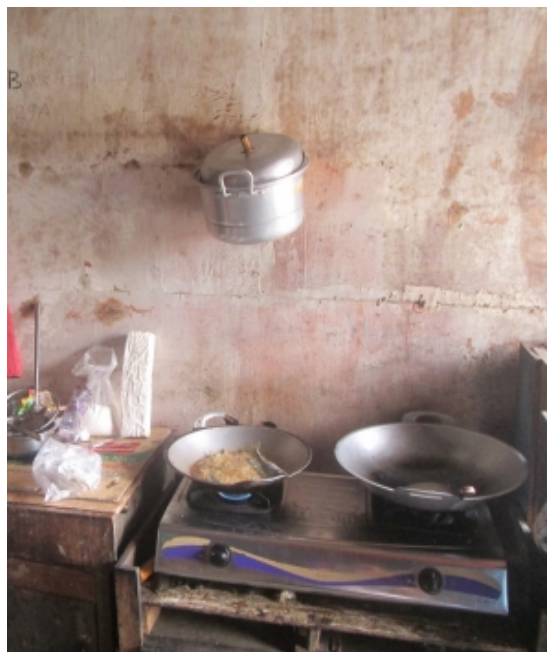

A. Kampung Bandan

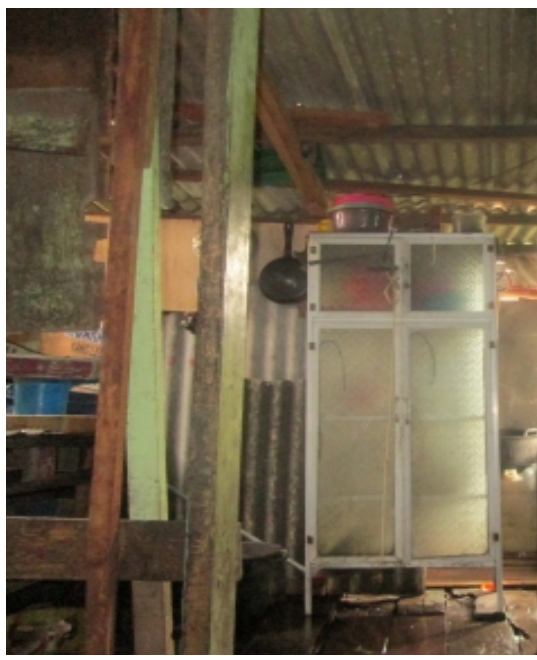

B. Kampung Luar Batang

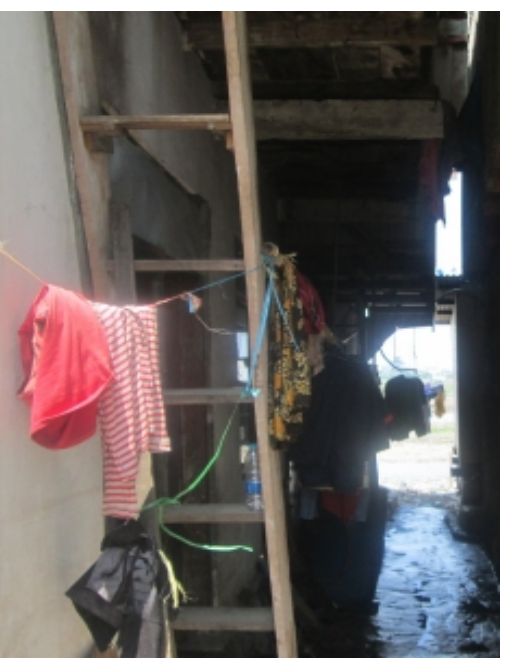

C. Kampung Muara Baru

Figure 14. Housing services of Kampungs in Jakarta

Source: The author.

Respondents were permitted to name more than one type of physical variables as the most important issues of kampungs. As shown in Table 2, there are fundamental differences in the prioritization of some physical characteristics. The spread of deteriorating housing was the first physical variable of cases A and B. However, case $\mathrm{C}$ suffered from a shortage of housing spaces, and residents viewed this factor as a first physical variable. The lack of housing services was the third physical variable of all cases A, B, and C. The analysis of the survey showed that all of these kampungs suffered from a shortage of housing services such as bathrooms, kitchens, and laundry rooms. The remaining physical status variables included a lack of lighting and ventilation, existence of structural problems, spread of abandoned buildings, and high-density construction. Finally, three of sixty respondents suggested other physical variables such as the complexity of the urban fabric, differing sizes of urban blocks and forms of construction. Fig. 15 shows the classification of physical status based on respondents' views of all cases. According to respondents' views, the main variables mentioned most frequently are the spread of the deteriorating housing 39 , shortage of housing spaces 39 , the lack of housing services 34 , and temporary construction materials 15 .

Table 2. Respondents' views on the physical status of kampungs in Jakarta

\begin{tabular}{llcccc}
\hline Physical status & \multicolumn{3}{c}{ Cases } & Total \\
& & A & B & C & \\
\hline 1 & Deteriorating housing & 19 & 9 & 11 & 39 \\
2 & Shortage of housing spaces & 17 & 9 & 13 & 39 \\
3 & Lack of housing services (bathrooms, kitchens) & 17 & 7 & 10 & 34 \\
4 & Temporary construction materials & 3 & 4 & 8 & 15 \\
5 & Lighting and ventilation & 5 & 2 & 5 & 12 \\
6 & Structural problems & 2 & 3 & 5 & 10 \\
7 & Abandoned buildings & 2 & 2 & 2 & 6 \\
8 & High-density construction & 2 & 0 & 2 & 4 \\
9 & Others & 2 & 0 & 1 & 3 \\
\hline
\end{tabular}

Note: A. Kampung Bandan; B. Kampung Luar Batang; C. Kampung Muara Baru.

Source: Survey by the author. 


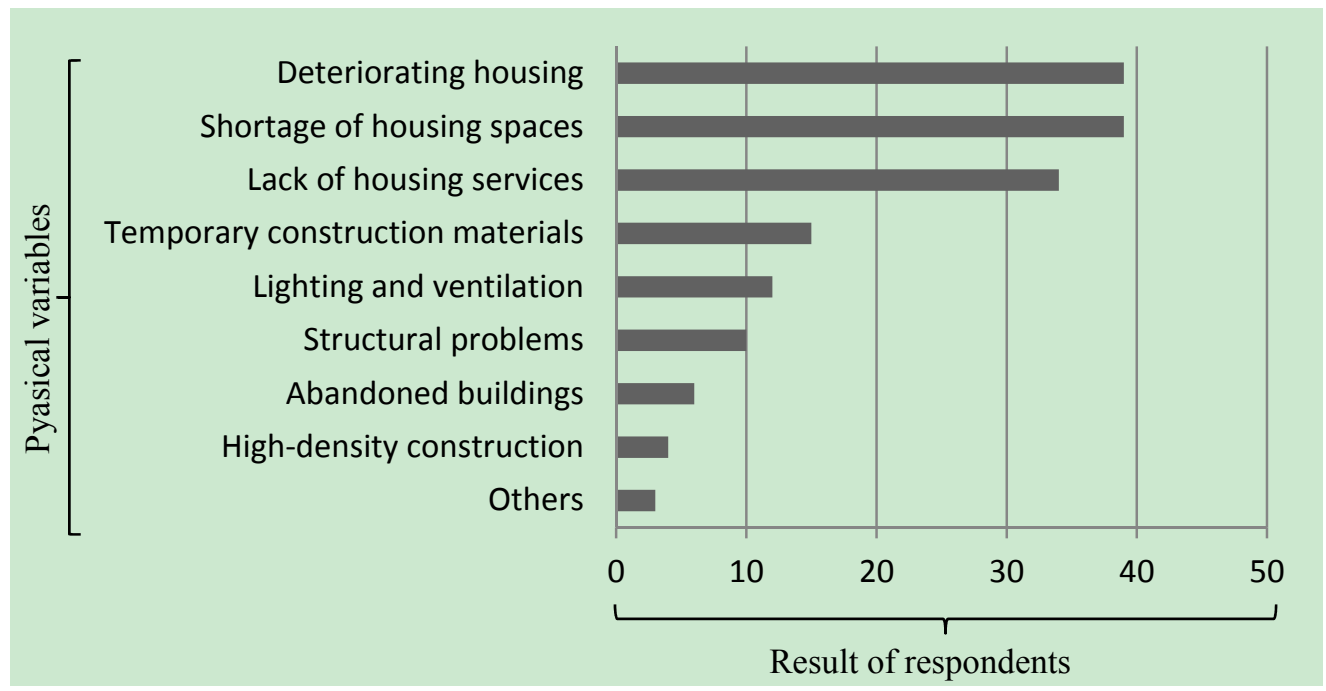

Figure 15. The classification of physical status of kampungs in Jakarta

Source: Survey by the author.

\subsection{Utility}

The current status of utilities does not comply with the standards for a healthy environment in urban communities. There are no piped water, private toilets and sewage system in these kampungs. Residents suffer from difficulty obtaining water due to the lack of water sources or sanitary water tanks in each house. As shown in Fig. 16, access to water through water reservoirs or public taps is challenging in these kampungs. The electricity is distributed among families through poles that hang between the housing in a way that does not take into account safety and security systems. Moreover, none of these kampungs have stormwater or sewage networks. Therefore, these settlements suffer from constant flood risk due to the lack of drainage systems. Some residents adapt to this situation by using bamboo for the houses' pillars to protect them from flood risks, as is the case in B and C. typically, People cooperate to prevent risks using available means.

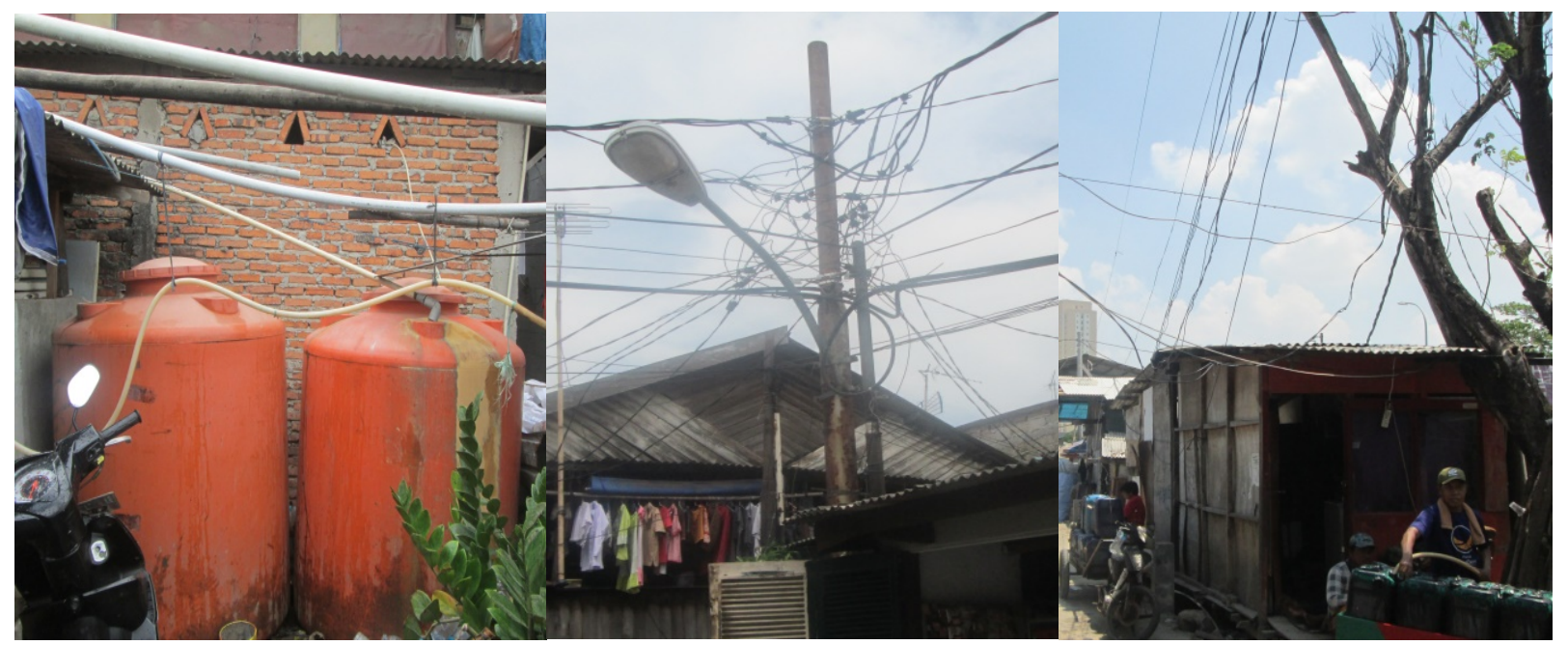

\section{A. Kampung Bandan \\ B. Kampung Luar Batang \\ C. Kampung Muara Baru}

Figure 16. Forms of water and electricity supply of kampungs in Jakarta

Source: The author.

Respondents were permitted to name more than one type of utility variables as the most important issues of kampungs. As shown in Table 3, there are fundamental differences among the priorities of some utility 
characteristics. The forms of water supply were the first utilities mentioned in settlements A and B. However, it was the third variable of settlement $\mathrm{C}$. The respondents viewed the problem of sewage as the first utility problem of settlement C. Moreover, the lack of cable, internet, telephone, and TV was the second utility variable in case A. However, it was the fifth in cases B and C. The remaining utility variables included problems with waste collection, gas supply systems, and rainwater drainage. The spatial location of the settlements played a role in determining these priorities. For instance, residents in settlements $\mathrm{B}$ and $\mathrm{C}$ indicated that sewage was one of the biggest problems due to the fact that these settlements were adjacent to the water, while settlement $\mathrm{A}$ was located in the inner city. Therefore, sewage drainage was not classified as a first priority. Finally, seven respondents suggested other utility variables including the lack of firefighting systems, heating, and alternative power systems. Fig. 17 shows the classification of utility variables based on respondents' views of all cases. According to respondents' views, the main variables mentioned most frequently are the forms of water supply 32 , waste water sewage 25 , problems with waste collection 25 , and forms of electricity connection 22 .

Table 3. Respondents' views on the utility status of kampungs in Jakarta

\begin{tabular}{llcccc}
\hline \multicolumn{2}{l}{ Utility status } & \multicolumn{3}{c}{ Cases } & Total \\
\hline 1 & Forms of water supply & A & B & C & \\
2 & Waste water sewage & 15 & 10 & 7 & 32 \\
3 & Problems with waste collection & 7 & 6 & 12 & 25 \\
4 & Forms of electricity connection & 8 & 5 & 12 & 25 \\
5 & Cable, internet, telephone, TV & 7 & 6 & 9 & 22 \\
6 & Gas systems & 10 & 5 & 6 & 21 \\
7 & Rainwater drainage & 7 & 5 & 4 & 16 \\
8 & Others & 3 & 5 & 4 & 12 \\
\hline
\end{tabular}

Note: A. Kampung Bandan; B. Kampung Luar Batang; C. Kampung Muara Baru.

Source: Survey by the author.

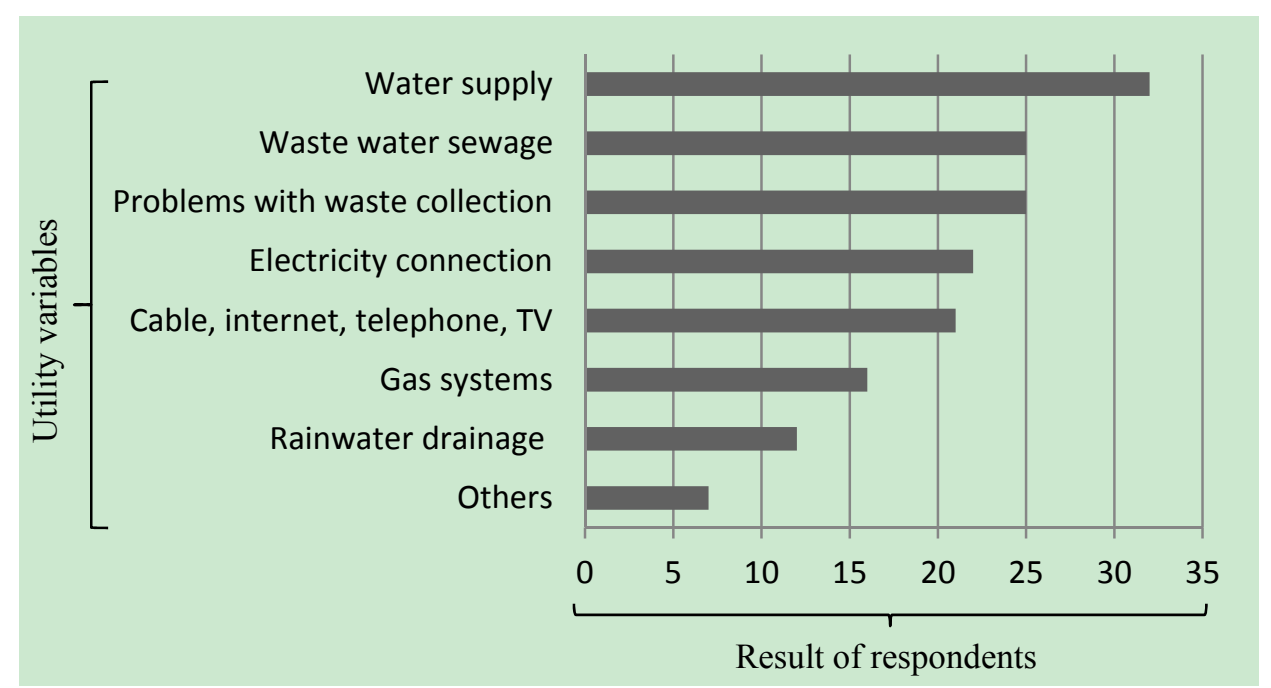

Figure 17. The classification of utility of kampungs in Jakarta

Source: Survey by the author.

\subsection{Public Facility}

The current status of facilities in kampungs does not comply with facility standards, population needs, and density. These kampungs are not subject to the standards of urban planning in the distribution of services. Therefore, most of the facilities are created by the population's efforts, such as children's playgrounds, 
recreational spaces, and shops. Facilities in these kampungs are characterized by a shortage of major services such as shopping centers, schools, and health services. In addition, there is a lack of recreational facilities such as children's playgrounds, parks, and public spaces. The open spaces in kampungs are very narrow and inadequate. As shown in Fig. 18, some residents put forth their own effort to develop children's playgrounds or use spaces between buildings as recreational spaces. I noticed that children played in these narrow lanes between houses or in places surrounded by waste. However, some facilities are being developed by the government in areas adjacent to kampungs such as schools, health services, and postal services. Therefore, many residents suffer from a lack of access to these facilities because they are located outside of walking distance.

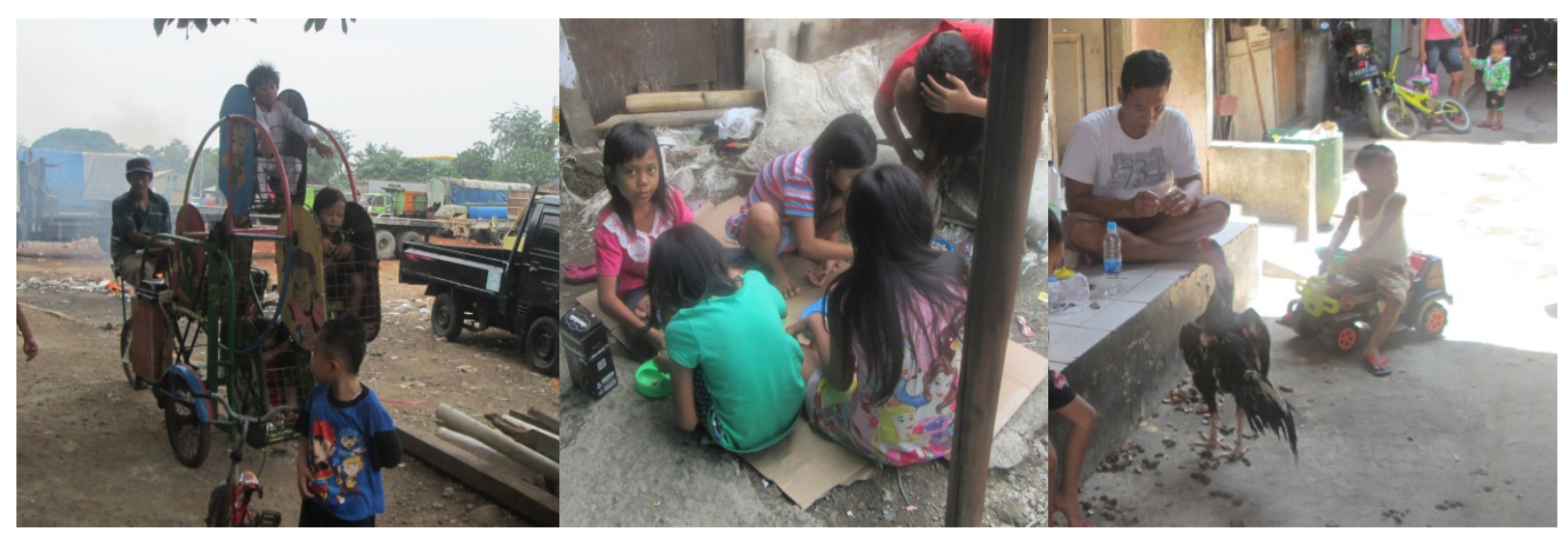

A. Kampung Bandan

B. Kampung Luar Batang

C. Kampung Muara Baru

Figure 18. Children's playgrounds of kampungs in Jakarta

Source: The author.

Respondents were permitted to name more than one type of public facility as the most important variables of kampungs. As shown in Table 4, there are fundamental differences among the priorities of some facility problems. The lack of children's playgrounds was the first prioritized variable in cases B and C. However, case A suffered from a shortage of health services as the first problem. A lack of shops and children's playgrounds was the second prioritized variable of facilities in case A. However, narrow streets and a lack of parks were the second prioritized in cases $\mathrm{B}$ and $\mathrm{C}$, respectively. The population and structural density played a defining role in these priorities. For instance, there was high structural density in settlements B and C, compared with settlement A. The remaining variables included the lack of schools, public spaces, health services, security services, religious facilities, and public transportation. Finally, two of sixty respondents suggested other facility variables such as the lack of social activities. Fig. 19 shows the classification of public facility problems based on respondents' views in all kampung cases. According to respondents' views, the main variables mentioned most frequently are the lack of children's playgrounds 33, lack of parks 24, lack of health services 23 and lack of shops 22 .

Table 4. Respondents' views on public facility of kampungs in Jakarta

\begin{tabular}{llcccc}
\hline Public facilities & \multicolumn{3}{c}{ Cases } & Total \\
& & A & B & C & \\
\hline 1 & Lack of children's playgrounds & 12 & 9 & 12 & 33 \\
2 & Lack of parks & 11 & 5 & 8 & 24 \\
3 & Lack of health services & 13 & 3 & 7 & 23 \\
4 & Lack of shops & 12 & 3 & 7 & 22 \\
5 & Lack of schools & 10 & 4 & 6 & 20 \\
6 & Narrow streets & 9 & 6 & 4 & 19 \\
7 & Lack of security services & 5 & 4 & 6 & 15 \\
8 & Lack of parking & 7 & 2 & 4 & 13
\end{tabular}




\begin{tabular}{llllll}
9 & Lack of public spaces & 5 & 2 & 4 & 11 \\
10 & Lack of religious facilities & 2 & 2 & 5 & 9 \\
11 & Lack of walkways & 2 & 2 & 4 & 8 \\
12 & Lack of public transportation & 4 & 2 & 1 & 7 \\
13 & Lack of postal services & 2 & 1 & 1 & 4 \\
14 & Others & 0 & 0 & 2 & 2 \\
\hline
\end{tabular}

Note: A. Kampung Bandan; B. Kampung Luar Batang; C. Kampung Muara Baru.

Source: Survey by the author.

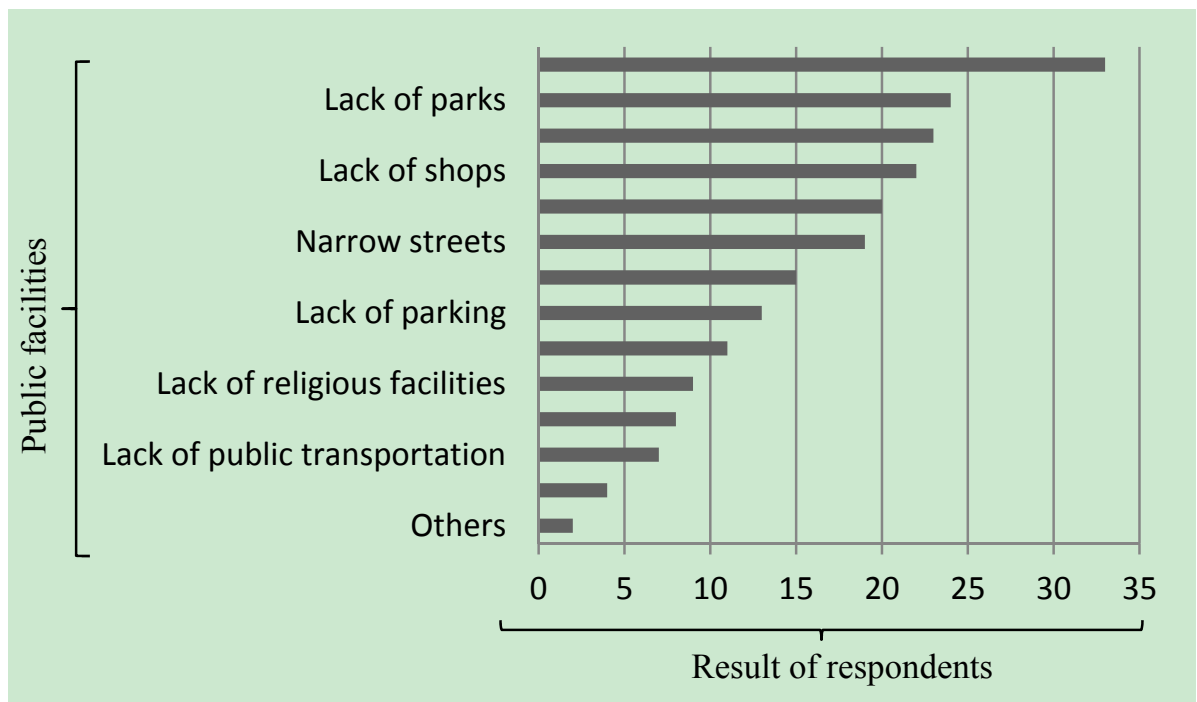

Figure 19. The classification of public facility of kampungs in Jakarta

Source: Survey by the author.

\section{Urban Upgrading Strategies}

The strategy of upgrading informal settlements in Jakarta should be based on a comprehensive plan that enhances community participation and reflects the needs of residents of those settlements. Upgrading informal settlements can continue within the framework of sustainable development and justice for future generations. The Urban Empowerment Program is one of the most important programs to settle population in these kampungs, helping to lift themselves out of poverty and improve livelihoods (WorldBank, 2010). The urban empowerment plan helps to improve the economic and social conditions of residents and increase community satisfaction. Strategy is subject to the participation of local communities in decision making and prioritizing the fulfillment of needs (Safarabadi, Moayedfar, \& Varesi, 2015). The urban upgrading plan must be taken into account to be consistent with the demographics, structural density, family size, and economic dimensions. In this strategy, the establishment of local civil organization is one of the important ways to encourage community participation to pursue their wants and fulfill their needs. As shown in Fig.20 the urban empowerment program should be based on upgrading social, cultural and economic structures through the development of education and training programs. In addition, The establishment of sustainable projects in these settlements can provide formal employment opportunities for skilled, unskilled and unemployed workers, especially women (UN-Habitat, 2003). Improving the urban environment must be in line with the methods used to upgrade the living conditions and skills to increase revenue sources and achieve social integration. Typically, government policies do not coincide with the needs of the population because of the "overlapping conflict" between the interests of the local government and the local community (Supriyatno, 2014). Therefore, the operational plan should involve stakeholders, such as representatives of the government, international donors, private sector, 'developers in the surrounding areas', and civil institutions. 


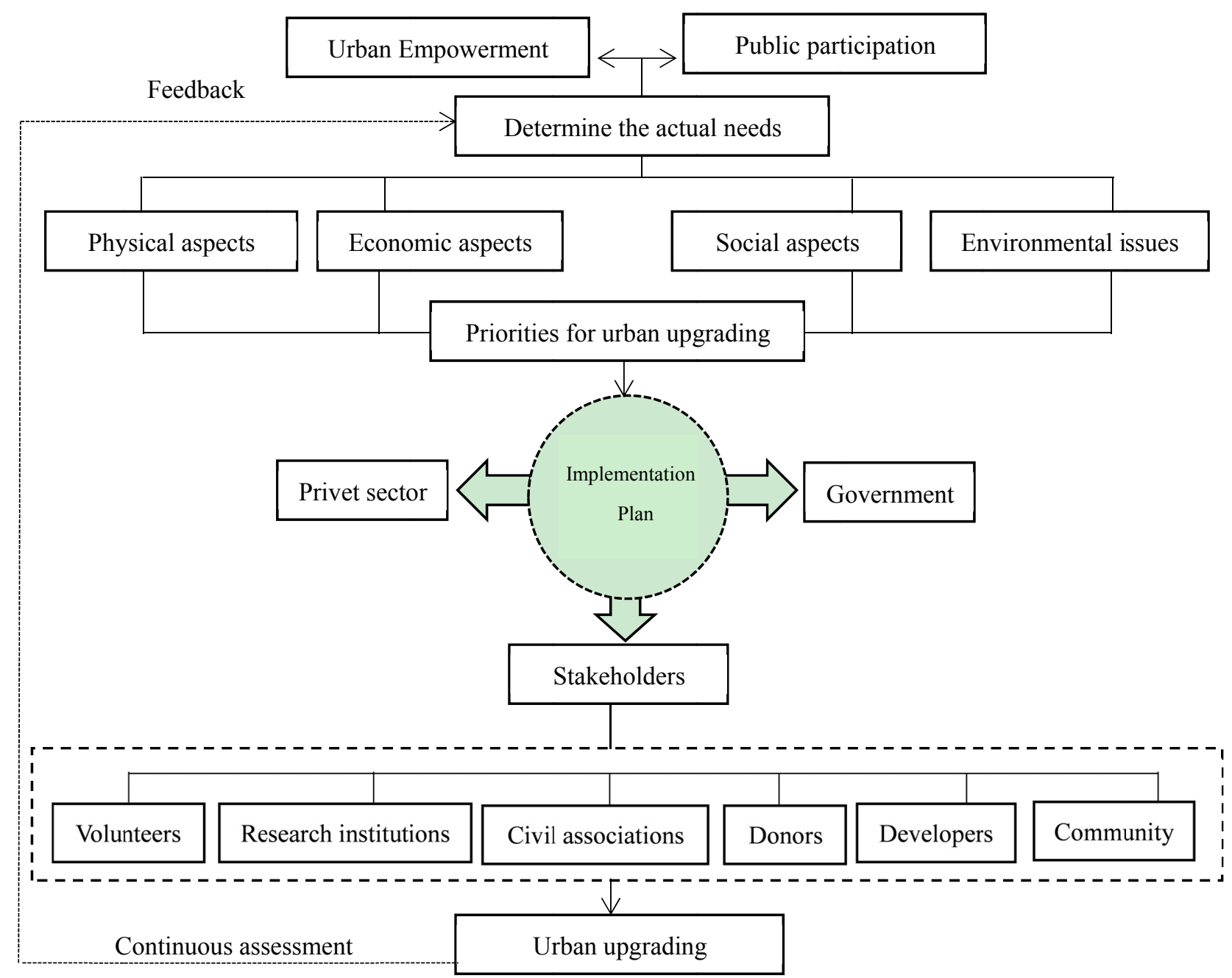

Figure 20. Framework of urban upgrading of informal settlements in Jakarta

Source: Author based on the results.

\section{Conclusion}

The proliferation of informal settlements in Jakarta is an inevitable consequence of the lack of regional planning, rapid urbanization, and high cost of housing. The economic inequality and the large gap in the distribution of wealth contributed to the urban disparity in Jakarta, where large parts of the city are divided spatially by class and race. The existence of the modern city and the kampung reflects the inequality and socio-economic marginalization in Jakarta (Firman, 2004). Informal settlements provide a convenient place for migrants seeking economic opportunities in major cities. Low-income households forced to live in informal settlements because of inadequate supply of affordable housing (UN-Habitat, 2011). In most cases, households are unable to find the same or better quality than their houses outside kampungs (Subroto, 2006). The real problem is not in the existence of informal settlements but in upgrading them physically without destroying social and economic structures.

The government has made efforts to develop the kampung through several policies including urban improvement, upgrading and resettlement. During the implementation of KIP program (1969-1974), the government was able to improve the living standards of 1.2 million people. At the end of 1982, the program contributed to improvement of 5 million urban poor (UN-Habitat, 2006). The kampung development policies have contributed to the reduction of urban degradation in these settlements, where degraded areas have declined from 392 in 2011 to 223 areas in 2013 (Nurdiansyah, 2018). The proportion of urban population living in poor areas also declined from 51 in 1990 to $22 \%$ in 2014 (UN-Habitat, 2016). The program has contributed to the improvement of the 
external environment of kampungs but there is an urgent need to develop the internal environment of residential units and improve the level of lighting and ventilation.

This paper discussed the urban status of informal settlements in Jakarta based on the field observation and analysis of residents' views. Results show that respondents agree that major issues characterize these kampungs are deteriorating housing, shortage of housing spaces, and a lack of housing services, children's playgrounds, water supply, sewage, waste collection, and parks. However, there are some differences among the priorities of urban variables of these settlements based on different spatial locations, demographics, and population density. In this paper, the conclusion is that the residents of kampungs are able to create urban environments separate from government regulations. They are able to adapt to unhealthy environments, such as deteriorated houses, flood risks, waste accumulation, and a lack of clean water (Simarmata \& Entwicklungsforschung, 2015). These settlements provide accommodation, living, and stability for its inhabitants at a cost that they can afford (UN-Habitat, 2003). Families in kampungs have succeeded in community organization to overcome the economic situation and insecure tenure, where hazards lead to the emergence of a creative community (Wilhelm, 2011). The formation of the urban environment in these kampungs reflects the desires and needs of the poor. Therefore, the urban status should be improved in accordance with a comprehensive plan determined by the resident's priorities. As shown in Table 5, the urban upgrading plan should reflect the current urban status of informal settlements based on urgent, medium, and low development priorities that will help to rationalize government spending. This framework is derived from understanding the standards of living by examining the physical status of those settlements.

Table 5. Evaluating urban status of informal settlements in Jakarta

\begin{tabular}{|c|c|c|c|c|c|c|}
\hline \multicolumn{3}{|r|}{ list of urban status } & \multicolumn{3}{|c|}{ Cases } & \multirow{3}{*}{\begin{tabular}{|c|} 
Total \\
39
\end{tabular}} \\
\hline & & & \multirow{2}{*}{$\frac{\mathrm{A}}{19}$} & \multirow{2}{*}{$\frac{\mathrm{B}}{9}$} & \multirow{2}{*}{$\frac{\mathrm{C}}{11}$} & \\
\hline \multirow{8}{*}{ 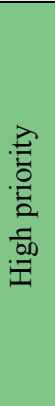 } & 1 & Deteriorating housing & & & & \\
\hline & 2 & Shortage of housing spaces & 17 & 9 & 13 & 39 \\
\hline & 3 & Lack of housing services (bathrooms, kitchens) & 17 & 7 & 10 & 34 \\
\hline & 4 & Lack of children's playgrounds & 12 & 9 & 12 & 33 \\
\hline & 5 & Water supply & 15 & 10 & 7 & 32 \\
\hline & 6 & Waste water sewage & 7 & 6 & 12 & 25 \\
\hline & 7 & Problems with waste collection & 8 & 5 & 12 & 25 \\
\hline & 8 & Lack of parks & 11 & 5 & 8 & 24 \\
\hline \multirow{8}{*}{ 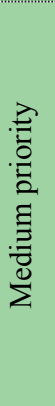 } & 9 & Lack of health services & 13 & 3 & 7 & 23 \\
\hline & 10 & Lack of shops & 12 & 3 & 7 & 22 \\
\hline & 11 & Electricity connection & 7 & 6 & 9 & 22 \\
\hline & 12 & Cable, internet, telephone, TV & 10 & 5 & 6 & 21 \\
\hline & 13 & Lack of schools & 10 & 4 & 6 & 20 \\
\hline & 14 & Narrow streets & 9 & 6 & 4 & 19 \\
\hline & 15 & Gas systems & 7 & 5 & 4 & 16 \\
\hline & 16 & Temporary construction materials & 3 & 4 & 8 & 15 \\
\hline \multirow{8}{*}{ 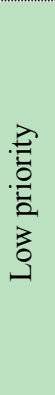 } & 17 & Lack of security services & 5 & 4 & 6 & 15 \\
\hline & 18 & Lack of parking & 7 & 2 & 4 & 13 \\
\hline & 19 & Lighting and ventilation & 5 & 2 & 5 & 12 \\
\hline & 20 & Rainwater drainage & 3 & 5 & 4 & 12 \\
\hline & 21 & Lack of public spaces & 5 & 2 & 4 & 11 \\
\hline & 22 & Structural problems & 2 & 3 & 5 & 10 \\
\hline & 23 & Lack of religious facilities & 2 & 2 & 5 & 9 \\
\hline & 24 & Lack of walkways & 2 & 2 & 4 & 8 \\
\hline
\end{tabular}

Note: A. Kampung Bandan; B. Kampung Luar Batang; C. Kampung Muara Baru.

Source: Survey by the author. 
As a recommendation, there are some aspects that need to be considered.

1) A comprehensive national plan should be developed to reduce the emergence of new informal settlements by developing small cities, controlling migration to major cities, and developing rural areas.

2) Housing policies should be more dynamic to promote the principle of 'community satisfaction'. This includes the diversification of housing patterns, construction laws, and land division.

3) The creation of comprehensive national databases of poverty and informal settlements, including urban, economic and social statistics that link spatial analysis systems is the key to dealing with informal settlements.

4) The private sector must play a key role in supporting the housing sector through financing, development, and implementation. Private sector stimulation starts with the development of local investment regulations, which include providing developers with land, tax breaks, and subsidizing low-cost housing projects.

5) Expanding subsidized housing programs targeted at vulnerable groups through the involvement of charitable, voluntary, community-based, and international donors.

6) The urban upgrading of the kampungs should include gradual urban improvement based on priorities list determined by the residents, which will contribute to the rationalization of government financial resources.

7) The urban upgrading projects of kampungs should take into consideration the continuous assessment of the population's desires and satisfaction; thus, the new urban environment does not negatively affect the economic and social conditions of the residents.

\section{References}

Abouelmagd, D. (2011). Housing for low-income Groups in Greater Cairo: An Interpretation of Polanyi's Modes of Economic Integration. Paper presented at the 12th Naerus Conference, Madrid.

Ali, M. H. S., \& Salim, M. (2006). The Causes and Consequences of the Informal Settlements in Zanzibar. Retrieved from https://www.fig.net/resources/proceedings/fig_proceedings/fig2006/papers/ts35/ts35_01_ali_sulaiman_032 $0 . p d f$

Alzamil, W. (2011). The Experiences of Governments in Dealing with Squatter Settlements: Comparative Analysis of Cases of Squatter Settlements in Egypt: Lap Lambert Academic Publishing GmbH KG.

Baker, J. L. (2012). Climate Change, Disaster Risk, and the Urban Poor: Cities Building Resilience for a Changing World. World Bank Publications. https://doi.org/10.1596/978-0-8213-8845-7

Bank, A. D. (2014). Urban Poverty in Asia. Asian Development Bank.

BPS. (2013). Evaluasi RW Kumuh di Provinsi DKI Jakarta Tahun 2013.

Bueno, F., \& Sedeh, V. (2011). Improving Slums: Stories from Sao Paulo. Washington DC.

Correa, C. (2000). Housing and Urbanization: Building Solutions for People and Cities. London: Thames \& Hudson.

Damayanti, R., \& Kossak, F. (2016). Examining Spatial Identity of Kampungs Through Young Adults' Perception in Surabaya - Indonesia. Journal of Architecture and Urbanism, 40(1), 18-28. https://doi.org/10.3846/20297955.2016.1150222

Djajadiningrat, H. (1994). Sustainable Urban Development in the Kampung Improvement Programme: A Case Study of Jakarta-Indonesia. University of Sheffield.

DKI-Jakarta. (2010). Ekstrim Di DKI Jakarta. Jakarta.

DKI-Jakarta. (2011). Rencana Tata Ruang Wilayah DKI Jakarta 2010- 2030. Draft Perda. DKI Jakarta: Bappeda.

Dumashie, D. A. (2004). Informal Housing in East Africa: Lessons Learned From Cross Country Borders. Paper presented at the TS12 Housing - Costs and Finance, Athens, Greece.

Fernandes, E. (2008). Informal settlements in Syria: a general framework for understanding and confronting the phenomenon. Retrieved from https://www.scribd.com/document/136857313/Informal-Settlements-in-Syria 
Firman, T. (2004). New town development in Jakarta Metropolitan Region: a perspective of spatial segregation. Habitat International, 28(3), 349-368. https://doi.org/10.1016/S0197-3975(03)00037-7

Gabriel, B. (2007). Informal Settlements in SEE - A regional support approach Spatial Information Management toward Legalizing Informal Urban Development. Paper presented at the Informal Settlements - Real Estate Markets Needs Related to Good Land Administration and Planning, Athens. Retrieved from http://library.tee.gr/digital/m2267/m2267_gabriel.pdf

Galbreath, D. J. (2007). The Organization for Security and Co-operation in Europe (OSCE). Taylor \& Francis.

Gillette, H. (2012). Civitas by Design: Building Better Communities, from the Garden City to the New Urbanism. University of Pennsylvania Press.

Hegazy, I. (2016). Informal settlement upgrading policies in Egypt: towards improvement in the upgrading process. Journal of Urbanism International Research on Placemaking and Urban Sustainability, 9(3). https://doi.org/10.1080/17549175.2015.1009845

Jakarta, D. J. $\quad$ P. $\quad$ D. (2014). Jakarta Open Data. Retrieved from http://data.jakarta.go.id/dataset/data-jumlah-penduduk-dki-jakarta

Jibril, I. U. (2006). Resettlement Issues, Squatter Settlements and the Problems of Land Administration in Abuja, Nigeria's Federal Capital. Paper presented at the Promoting Land Administration and Good Governance 5th FIG Regional Conference, Accra, Ghana.

Leaf, M. (1993). Land rights for residential development in Jakarta, Indonesia: thecolonial roots of contemporary urban dualism. International Journal of Urban and Regional Research, 17(4), 477-491. https://doi.org/10.1111/j.1468-2427.1993.tb00236.x

Lombard, M. (2016). Land conflict in peri-urban areas: Exploring the effects of land reform on informal settlement in Mexico. Urban Studies, 53(13), 2700-2720. https://doi.org/10.1177/0042098015603569

Mata, D. D. (2013). Disentangling the Causes of Informal Housing. Paper presented at the 53st European Congress of the Regional Science Association International (RSAI), Palermo, Italy.

McCarthy, P. (2002). Urban Slums Reports: The case of Jakarta, Indonesia. Retrieved from http://www.ucl.ac.uk/dpu-projects/Global_Report/pdfs/Jakarta.pdf

Miller, M., Bobbette, A., \& Turpin, E. (2012). Jakarta: design research and the futures of hypercomplexity. MONU, 56-63.

Minnery, J., Argo, T., Winarso, H., Hau, D., Veneracion, C., Forbes, D., \& Childs, I. (2013). Slum upgrading and urban governance: Case studies in three South East Asian cities. Habitat Int., 39, 162-169. https://doi.org/10.1016/j.habitatint.2012.12.002

Napier, M. (2002). Informal settlement integration, the environment and sustainable livelihoods in sub-Saharan Africa. Retrieved from http://www.grif.umontreal.ca/pages/i-rec\%20papers/napier.pdf

NASA. (2005). Urban Growth in Jakarta, Indonesia. Retrieved from https://earthobservatory.nasa.gov/IOTD/view.php?id=5693

Nurdiansyah, A. (2018). Urban Slum Upgrading Policy in Jakarta (Case Study: Kampung Deret Program Implementation). The Indonesian Journal of Planning and Development, 3(1). https://doi.org/10.14710/ijpd.3.1.19-31

Olawuyi, D. S. (2016). The Human Rights-Based Approach to Carbon Finance. Cambridge University Press. https://doi.org/10.1017/CBO9781316226285

Pellissery, S., Davy, B., \& Jacobs, H. M. (2017). Land Policies in India: Promises, Practices and Challenges. Springer Singapore. https://doi.org/10.1007/978-981-10-4208-9

Penjaringan, K. K. (2013). Laporan Tahunan 2012 Kelurahan Penjaringan Jakarta Utara.

Potsiou, C. A. A., \& Clarissa. (2010). Informal urban Development in europe experiences from albania and greece. Nairobi.

Prasetyanti, R. (2015). Slum Kampong Tourism “Jakarta Hidden Tour”: Designing Eco-Cultural Based Pro-Poor Tourism. European Journal of Interdisciplinary Studies, 3, 111-122. https://doi.org/10.26417/ejis.v3i1.p111-122 
Safarabadi, A., Moayedfar, S., \& Varesi, H. (2015). Urban Sustainable Development with Emphasis on the Empowerment of Informal Settlements in Urban Areas. The Case of Yazd, Iran. European Journal of Geography, 6(1), 83-97.

Simarmata, H., \& Entwicklungsforschung, Z. (2015). How informal institutions manage flood-risk at community level: An empirical study of Kampung Muara Baru, Jakarta.

Soliman, A. M. (1996). Housing and sustainable development in developing countries. Rateb U.

Soliman, A. M., \& de Soto, H. (2004). A Possible Way Out: Formalizing Housing Informality in Egyptian Cities. University Press of America.

Srinivas, H. (2013). Defining Squatter Settlements. Retrieved from http://www.gdrc.org/uem/squatters/define-squatter.html

Steinberg, F., \& Bank, A. D. (2008). Revitalization of Historic Inner-city Areas in Asia: The Potential for Urban Renewal in Ha Noi, Jakarta, and Manila. Asian Development Bank.

Subroto, I. (2006). Preservation of Kampung Luar Batang, Sunda Kelapa, North Jakarta a Challenge to Redevelop a Slum. Jakarta.

Supriatna, A., \& Molen, P. ( 2014). Land readjustment for upgrading Indonesian kampung: A proposal. South East Asia Research, 22(3), 379-397. https://doi.org/10.5367/sear.2014.0218

Supriyatno, B. (2014). Role of Government in Jakarta Organize Slum Area. Scientific Research Journal (SCIRJ), $2(5)$.

Surveyors, I. F. O., \& Europa, F. N. Ø. K. F. (2015). Formalizing the Informal: Challenges and Opportunities of Informal Settlements in South-East Europe. International Federation of Surveyors.

Takahashi, K. (2009). Evolution of housing development paradigms for the urban poor: the post-war Southeast Asian Context. Journal of Asia Pacific Studies.

Turner, J. (2000). Housing By People: Towards Autonomy in Building Environments. New York: Marion Boyars Publishers Ltd.

Turok, I. (2014). The Evolution of National Urban Policies: A Global Overview. UN-Habitat.

UN-Habitat. (2003). The Challenge of Slums: Global Report on Human Settlements, 2003. Earthscan Publications.

UN-Habitat. (2005). Habitat Debate. $\quad$ Retrieved https://dokumen.tips/download/link/habitat-debate-vol11-no-3-the-mdgs-and-the-city

UN-Habitat. (2006). The world's first slum upgrading programme. Paper presented at the World Urban Forum 3 , Vancouver, Canada.

UN-Habitat. (2008). Housing Finance Mechanisms in Indonesia. United Nations Human Settlements Programme.

UN-Habitat. (2011). Affordable Land and Housing in Asia (Vol. 2). Nairobi United Nations Human Settlements Programme.

UN-Habitat. (2012a). Enhancing Urban Safety and Security: Global Report on Human Settlements 2007. Taylor $\&$ Francis.

UN-Habitat. (2012b). Global Urban Indicators Database.

UN-Habitat. (2013). State of the World's Cities 2012/2013: Prosperity of Cities. Taylor \& Francis.

UN-Habitat. (2015). Habitat III Issue Papers 'Informal Settlemetns'. Retrieved from http://unhabitat.org/wp-content/uploads/2015/04/Habitat-III-Issue-Paper-22_Informal-Settlements.pdf

UN-Habitat. (2016). Urbanization and Development: Emerging Futures.

Werthmann, C., \& Beardsley, J. (2008). Improving Informal Settlements: Ideas from Latin America. Harvard Design Magazine, 28.

Wilhelm, M. (2011). Approaching Disaster Vulnerability in a Megacity: Community Resilience to Flooding in two Kampungs in Jakarta (Doctor of Philosophy), University of Passau, Passau, Germany.

WorldBank. (1995). Indonesia Impact Evaluation Report Enhancing the Quality of Life in Urban Indonesia: The Legacy of Kampung Improvement Program. 
WorldBank. (2010). Jakarta: Urban Challenges in a Changing Climate. Jakarta: The World Bank.

WorldBank. (2011). Jakarta Case Study Overview Climate Change, Disaster Risk and the Urban Poor: Cities Building Resilience for a Changing World. Retrieved from http://siteresources.worldbank.org/INTURBANDEVELOPMENT/Resources/336387-1306291319853/CS_ Jakarta.pdf

Worldpopulationreview. N (2017). Jakarta $\quad$ Population. $\quad$ Retrieved from http://worldpopulationreview.com/world-cities/jakarta-population/

Wright, E. (2016). Poverty in Jakarta. Retrieved from http://borgenproject.org/poverty-jakarta/

Zhua, J., \& Simarmatac, H. (2015). Formal land rights versus informal land rights: Governance for sustainable urbanization in the Jakarta metropolitan region, Indonesia. Land Use Policy, 43, 63-73. https://doi.org/10.1016/j.landusepol.2014.10.016

\section{Copyrights}

Copyright for this article is retained by the author(s), with first publication rights granted to the journal.

This is an open-access article distributed under the terms and conditions of the Creative Commons Attribution license (http://creativecommons.org/licenses/by/4.0/). 